\title{
Ontogeny of osmoregulation in the Pacific blue shrimp, Litopenaeus stylirostris (decapoda, penaeidae): Deciphering the role of the $\mathrm{Na}+\mathrm{K}+-\mathrm{ATPase}$
}

\author{
Pham Dominique ${ }^{1,{ }^{*}}$, Charmantier Guy ${ }^{2}$, Boulo Viviane ${ }^{1,2}$, Wabete Nelly ${ }^{1}$, Ansquer Dominique, \\ Dauga Clément ${ }^{1}$, Grousset Evelyse ${ }^{2}$, Labreuche Yannick ${ }^{3,4, *, a}$, Charmantier Daures Mireille ${ }^{2, a}$
}

\footnotetext{
${ }^{1}$ Lagon, Environnement et Aquaculture Durable, Ifremer, Boulouparis, Nouvelle-Calédonie

2 Université de Montpellier, Adaptation Ecophysiologique et Ontogenèse, UMR 9190, Marbec, UM, CNRS, IRD, Ifremer, Place Eugène Bataillon, CC 092, 34095 Montpellier, Cedex 05, France

${ }^{3}$ Ifremer, Unite Physiologie Fonctionnelle des Organismes Marins, ZI de la Pointe du Diable, CS 10070,

F-29280 Plouzane, France

${ }^{4}$ Sorbonne Universités, UPMC Paris 06, CNRS, UMR 8227, Integrative Biology of Marine Models, Station Biologique de Roscoff, CS 90074, F-29688 Roscoff cedex, France
}

* Corresponding authors : Dominique Pham, Tel.:+33 6873525 83; fax: + 33687351177 ; email address : dominique.pham@ifremer.fr ; Yannick Labreuche, (33) 0298295647 ; fax: (33) 0298 292324 ; email address : ylabreuche@sb-roscoff.fr

${ }^{a}$ These authors co-supervised the work

\begin{abstract}
:
The role of the main ion transporting enzyme $\mathrm{Na}+/ \mathrm{K}+$-ATPase in osmoregulation processes was investigated in Litopenaeus stylirostris. The development and localization of the osmoregulation sites were studied during ontogenesis by immunodetection of $\mathrm{Na}^{+} \mathrm{K}^{+}$-ATPase using monoclonal antibodies and transmission electron microscopy (TEM). Osmoregulation sites were identified as the pleurae and branchiostegites in the zoeae and mysis stages. In the subsequent post-metamorphic stages the osmoregulatory function was mainly located in the epipodites and branchiostegites and osmotic regulation was later detected in the gills. The presence of ionocytes and microvilli in these tissues confirmed their role in ionic processes. The complete open reading frame of the mRNA coding for the $\alpha-$ subunit of $\mathrm{Na}+\mathrm{K}+$-ATPase was characterized in L. stylirostris. The resulting 3092-bp cDNA (LsNKA) encodes a putative 1011-amino-acid protein with a predicted molecular mass of $112.3 \mathrm{kDa}$. The inferred amino acid sequence revealed that the putative protein possesses the main structural characteristics of the $\mathrm{Na}+\mathrm{K}+$-ATPase $\alpha$-subunits.
\end{abstract}

Quantitative RT-PCR analyses indicated that LsNKA transcripts did not significantly vary between the different developmental stages. The number of transcripts was about 2.5-fold higher in the epipodites and gills than in any other tissues tested in juveniles. A reverse genetic approach was finally implemented to study the role of LsNKA in vivo. Knockdown of LsNKA expression by gene-specific dsRNA injection led to an increase of shrimp mortality following an abrupt salinity change compared to 
control animals. These data strongly suggest that LsNKA plays an important role in osmoregulation when the shrimp are challenged by changing salinities.

Keywords: penaeid, Litopenaeus stylirostris, ontogeny, osmoregulation, Na+/K+-ATPase, RNA interference 


\section{Introduction}

In New Caledonia (South Pacific) the shrimp culture industry is based upon the Pacific blue shrimp Litopenaeus stylirostris, an exogenous species imported in the early 1970s from Latin Americas and which represents today the second largest export business after the nickel industry. However, this production has been constantly decreasing in the last 4 years, in part because of recurrent difficulties encountered by the hatcheries to obtain nauplii and because of unexplained mortalities occurring during the larval rearing period. A better understanding of the key physiological functions of L. stylirostris in adapting to the surrounding environment is therefore needed to sustain this industry.

The establishment of a species in a given habitat relies on the ability of each of its developing stages to adapt to salinity (and to its abrupt changes) as it is one of the main environmental parameters that wields a selective pressure on aquatic organisms. As illustrated by the number of published studies, a large amount of information is now available regarding the processes involved in osmoregulation of crustacean adult stages (reviewed in Lucu and Towle, 2003; Charmantier et al., 2009; Henry et al. 2012). By comparison, data regarding the changes in ionoregulatory mechanisms occurring throughout the post-embryonic development remain relatively scarce. In crustaceans, three alternative ontogenetic patterns have been proposed (Charmantier, 1998). The first pattern corresponds to a weak osmoregulatory ability that does not predictably vary with the progress of developmental stages; the second pattern is based on the establisment of efficient osmoregulation in the first post-embryonic stages, comparable to those occurring in adults. Finally, in the third proposed pattern, the early postembryonic stages are osmoconformers or they slighty osmoregulate. Thereafter, a shift occurs at the metamorphic larva-juvenile transition and the animals gain osmoregulation capabilities which they keep into adulthood. Several penaeid shrimp belong to the latter group, including the Kuruma shrimp Penaeus japonicus (Charmantier, 1986; Charmantier et al., 1988) and the Pacific blue shrimp L. stylirostris (Pham et al., 2012), which, as adults, are hyper-hypo-osmoregulators .

In a great variety of adult decapod crustacean species and other aquatic invertebrates, osmoregulatory tissues in branchial cavity are restricted to the gills (Wheatly and Henry, 1987; Flick and Haond, 2000; Lignot et al, 2005). Different studies conducted in brachyuran crabs have pointed out that osmoregulatory structures are mainly located in 
the posterior gills, whereas anterior gill lamellae generally possess thin respiratory epithelia enabling diffusive gas exchange (Cieluch et al, 2004; Chung and Lin, 2006). However other epithelia in the branchial chamber (branchiostegite, pleura, epipodites) are involved in the osmoregulation processes in many species such as $P$. japonicus (Bouaricha et al., 1994), Crangon crangon (Cieluch et al., 2005) or Macrobrachium amazonicum (Boudour-Boucheker et al., 2013) depending on the developmental stage. As in adults, the occurrence of osmoregulation in young post-embryonic stages implies the existence of an efficient ionic regulation (mainly of $\mathrm{Na}^{+}$and $\mathrm{Cl}^{-}$ions) based on enzymes involved in ion transport. Among these enzymes, the $\mathrm{Na}^{+} / \mathrm{K}^{+}$-ATPase is considered to play a central role (Péqueux, 1995; Charmantier, 1998; Charmantier et al., 2001; Weihrauch et al., 2001; Castilho et al., 2001; Lucu and Towle, 2003; Charmantier et al., 2009; McNamara and Faria, 2012, Henry et al., 2012). The native holoenzyme is a tetramer composed of two catalytic units possessing the ATP binding site (the $\alpha$ subunits) of approximately $100 \mathrm{kDa}$ and two $\beta$-subunits of $40 \mathrm{kDa}$ thought to play a role in binding the complex in the basolateral membrane. In addition, the $\mathrm{Na}^{+} / \mathrm{K}^{+}$-ATPase has been shown in vertebrates to contain a third unit ( $\gamma$-subunit) that modulates the enzyme function according to the specific demands of a given tissue (Toyoshima et al., 2011). However, this latter subunit has not yet been characterized in any crustacean species. From a functional point of view, this sodium-pump enables ion transport directly through the transfert of $3 \mathrm{Na}^{+}$ions from the cytosol to the hemolymph in exchange of $2 \mathrm{~K}^{+}$using energy derived from ATP hydrolysis and indirectly via the establishment of ionic electrochemical gradients. This enzyme is therefore of particular interest to investigate the ontogeny of osmoregulation and to ascertain functional and morphological identification of ion transport.

The present study was aimed at investigating the development and localization of the osmoregulation sites during the post-embryonic development of L. stylirostris through the immunodetection of $\mathrm{Na}^{+} / \mathrm{K}^{+}$-ATPase activity using monoclonal antibodies. We also characterized the gene encoding the sodium-pump and measured its expression during post-embryonic development as well as in sub-adult animals using quantitative realtime PCR. Finally, this gene was silenced by RNA interference to provide further evidence for its in vivo role in the control of osmoregulation. 


\section{Material and methods}

\subsection{Animals}

L. stylirostris shrimp from a selected line (SPR43, Weppe et al., 1992) were obtained from the IFREMER facility (IFREMER, BP 2059, 98846 Noumea cedex, New Caledonia). Nauplii bred by unilateral eyestalk ablated females (Pham et al., 2012) were stocked at a density of 180 larvae. $\mathrm{L}^{-1}$ and maintained under constant conditions (35 ppt, $29^{\circ} \mathrm{C}$ and 14:10 h day:night photoperiod). Microparticles and Artemia nauplii were supplied ad libitum. From day 3, erythromycin (2 ppm) was added every other day to the tank water until day 9. After this period, seawater exchanges were performed at a $50 \%$ to $100 \%$ daily ratio as long as the animals were kept in the hatchery (i.e. 10 days after becoming postlarvae). After reaching PLA stage (i.e. 10 days old postlarvae at $29^{\circ} \mathrm{C}$ ), animals were transferred in $2 \mathrm{~m}^{3}$ nursery ponds at a density of 20/liter and reared till they reached PL7 stage or later stages, as confirmed by the rostral formula [5-0] (Pham et al., 2012). After harvesting, animals were stocked at a density of $2-4 / \mathrm{m}^{2}$ in earthen grow-out pond and fed ad libitum for experimental purposes. Water renewal rates were progressively increased from $5 \%$ to $15 \%$ a day for a duration of 4 months.

\subsection{Histology and immunofluorescence light microscopy}

Sections were prepared from stages Zoea 2 to PL9, and from $25 \mathrm{~g}$ adults. For larvae and postlarvae, whole animals were fixed in Bouin's fixative for $24 \mathrm{~h}$, rinsed and kept in $70 \%$ ethanol until further use. For adults, gills were dissected and fixed. Samples were washed and dehydrated in a graded ethanol series and embedded in Paraplast (Paraplast Plus, Sigma, P3683). Sections of $4 \mu \mathrm{m}$ were cut on a Leitz Wetzlar microtome, collected on poly-L-lysine-coated slides, and stored at $37^{\circ} \mathrm{C}$ for $48 \mathrm{~h}$. One series was used for classic light microscopy with Masson's trichome method for tissue topography, while the other series was used for immunohistology. The immunocytochemistry procedure has been previously described (Cieluch et al., 2005). Immunolocalization of $\mathrm{Na}^{+} / \mathrm{K}^{+}$-ATPase was done through immunofluorescence light microscopy using a rabbit polyclonal antibody $\mathrm{H} 300$ raised against an internal region of $\mathrm{Na}^{+} / \mathrm{K}^{+}$-ATPase $\alpha 1$ of human origin $\left[\mathrm{Na}^{+} / \mathrm{K}^{+}\right.$-ATPase $\alpha(\mathrm{H}-300)$; Santa Cruz Biotechnology]. This antiserum has previously been shown to display positive and specific immunoreactivity toward the $\mathrm{Na}^{+} / \mathrm{K}^{+}$-ATPase of several crustaceans (Boudour-Boucheker et al., 2014). 


\subsection{Transmission Electron Microscopy}

Transmission electron microscopy was done as previously described by Martinez et al. (2005). Briefly, PL9 postlarvae were fixed for $24 \mathrm{~h}$ with $2.5 \%$ glutaraldehyde in a mixture of freshwater and seawater adjusted to the hemolymph osmotic pressure. Following rinsing, gills, epipodites and branchiostegistes were excised and post-fixed for $2 \mathrm{~h}$ at $4^{\circ} \mathrm{C}$ in osmic acid $\left(\mathrm{OsO}_{4}\right)$, washed in distilled water and dehydrated in a graded ethanol series and propylene oxide, then embedded in Spurr's resin. Semithin and ultrathin sections were cut on a Reichert OMU3 ultramicrotome. Semithin sections were stained with toluidine blue, while ultrathin sections were contrasted with $2 \%$ uranyl acetate in $70^{\circ}$ ethanol and lead citrate. Observations were made on a JEOL 1200 EX2 transmission electron microscope at $70 \mathrm{kV}$.

\subsection{RNA extractions and full-length cDNA cloning of $L s N K A$}

Fresh tissues, including eyestalk (Ey), hepatopancreas (Hp), gills (Gi), epipodites (E), pleopods $(\mathrm{Pl})$, abdominal muscle $(\mathrm{Mu})$, were collected from five shrimp $($ mean weight $=$ $30 \mathrm{~g}$ ) as parallel samples for subsequent RNA extractions. Larvae were collected from the following stages: nauplius (Nii), zoea II (Z2), mysis II (M2), postlarvae I (P1). Three pools were used as replicates. Tissues and larvae were kept in RNA later reagent (Ambion) following sampling and stored at $-20^{\circ} \mathrm{C}$ until further use. Total RNA was extracted using RNeasy columns (Qiagen) according to the manufacturer's instructions. RNA quantity, purity and integrity were verified spectrophotometrically $\left(A_{260} / A_{280}\right)$ and by electrophoresis on $1 \%$ agarose gels.

To isolate a cDNA of $L s N K A$, specific primers (A-120 and A-122, Table 1) were designed on highly-conserved regions from Penaeus monodon and Homarus americanus $\mathrm{Na}^{+} / \mathrm{K}^{+}$-ATPase $\alpha$-subunit nucleotide sequences (accession numbers: AY140650.1 and DQ399796.1, respectively) and from L. vannamei expressed sequence tag (EST) sequences, available at www.marinegenomics.org (Marine Genomics accession numbers: MGID368619 et MGID455880) (for a review, see Lucu and Towle, 2003; O’Leary et al., 2006). A PCR was subsequently performed to amplify a 1180-bp amplicon from gill cDNA. After sequencing by GATC-Biotech (Konstanz, Germany) a BlastX match of this fragment revealed high sequence homologies (>98\% identities) with the $\mathrm{Na}^{+} / \mathrm{K}^{+}$-ATPase anucleotide sequence from $P$. monodon (accession number: EF672699.1) and Fenneropenaeus indicus (accession number: HM003691.1). Based on $P$. monodon and $F$. indicus nucleotide sequence alignment a new set of 
primers (A-119 and A-132, Table 1) was designed in the 5'- and 3'-regions and used to generate the full-length cDNA of LsNKA.

\subsection{Sequence data analysis and phylogenetic tree construction}

A list of known sequences of the members of NKA proteins was obtained from GenBank and EMBL databases using the BLAST (Basic Local Alignment Search Tool) program (Altschul et al., 1997). Sequence alignments were performed using CLUSTAL O software (http://www.ebi.ac.uk/Tools/msa/clustalo/). The identification of putative protein motifs was performed using the MotifScan softwares (Pfam HMMs global models database) available at SIB (Swiss Institute of Bioinformatics; http://hits.isb-sib.ch), the Protein motifs Search (http://www.ebi.ac.uk/Tools/ppsearch/) and the TMPRED program available at EMBnet (European Molecular Biology Network, http://www.ch.embnet.org/software/TMPRED_form.html). The theoretical isoelectric point $(\mathrm{pI})$ and molecular weight $(\mathrm{Mw})$ were estimated by the ProtParam Tool (http://web.expasy.org/protparam/). Trees were built using the MEGA software (Molecular Evolutionary Genetics Analysis, version 5.0) applied to the NeighborJoining and maximum likelihood methods (Felsentein, 1985; Tamura et al., 2007). Bootstrap values $(\%)$ of 1000 replicates were calculated for each node of the consensus tree obtained.

\subsection{Preparation of dsRNA}

Double-stranded RNAs (dsRNA) were generated as previously described (Labreuche et al., 2009). Briefly, the DNA template used for in vitro transcription was pCR4 vector (Invitrogen) hosting a 298-bp portion of LsNKA cDNA. The formation of dsRNA was monitored by determining the size shift in $1 \%$ agarose gel electrophoresis. Finally, dsRNAs were diluted to a final concentration of $250 \mathrm{ng} / \mu \mathrm{l}$ in sterile saline solution (10 mM Tris- $\mathrm{HCl} \mathrm{pH} 7.5,400 \mathrm{mM} \mathrm{NaCl}$ ) and stored at $-80^{\circ} \mathrm{C}$.

In order to test the effectiveness of dsRNA injections, 240 Shrimp (1.0-1.5 g) were brought to the laboratory for acclimation (salinity $27 \mathrm{ppt}$ ). After 5 days, the animals were intramuscularly injected between the third and fourth abdominal segment with either $10 \mu \mathrm{g}$ ( $20 \mu \mathrm{l}$ volume) of dsRNA or the same volume of injection buffer as a control, and returned to two different culture tanks. Forty-eight hours after treatment, gills were excised from 10 animals from each treatment and kept in RNA later reagent (Ambion) and stored at $-20^{\circ} \mathrm{C}$ for subsequent RNA extractions. At the same time, an 
acute salinity exposure experiment was performed to investigate the effects of $L s N K A$ dsRNA injection on shrimp survival. To this end, dsRNA-injected and control shrimp were exposed to salinities of 5, 27 and 40 ppt in 30 liter glass tanks. This experiment was conducted in triplicates with 10 shrimp per tank. Mortality was recorded after 48 hours.

\subsection{Quantitative real-time PCR}

Quantitative real-time RT-PCR (qPCR) was performed on an ABI 7300 system as previously described (Labreuche et al., 2010). Amplification efficiencies for all qPCR primers were determined according to Pfaffl et al. (2002) and the specificity of the PCR amplification was verified from the melting curve. Each run included the cDNA control, negative controls (total RNA treated with DNase I), and blank controls (water). The relative mRNA expression levels were determined using the two standard curve methodology (QuantiTect® SYBR Green PCR Handbook). The elongation factor 1alpha gene (EF1, accession no. AY117542.1) was used as the internal reference (normaliser) mRNA (de Lorgeril et al., 2008). Real-time PCR primer sequences are indicated in Table 1.

\subsection{Statistical analysis}

All numerical data were expressed as the mean \pm standard error. One-way analysis of variance (ANOVA) or the Kruskal-Wallis test was used for mRNA expression analysis. These statistical analyses were performed with Statgraphics Plus 5.0 software. 


\section{Results}

\subsection{Histology and $\mathrm{Na}^{+} / \mathrm{K}^{+}$-ATPase immunolocalization}

NKA distribution was visualized using immunohistochemistry (Fig. 1). The resulting data are summarized in Table 2. A positive immunoreactivity for $\mathrm{Na}^{+} / \mathrm{K}^{+}$-ATPase could be observed in zoea 2, restricted to the epithelium of the pleurae in the branchial cavity (Table $2 \&$ Fig. 1A). At this larval stage, optical microscopy allowed the identification of well-developed branchiostegites, which were observed without any immunolabelling, whereas epipodites and gills appeared undifferentiated. In mysis 2 , a positive immunolabeling was detected along the inner epithelium of the branchiostegites. At this stage, simple evaginations of the body wall formed early gill buds, free of fluorescence staining (Fig. 1B). At PL1, epipodites were clearly observed, showing a strong immunofluorescence compared to the other positive organs of the branchial cavity (i.e. the branchiostegites and pleurae) (Fig. 1C). At PL4, gill filaments were easily observable but remained free of immunofluorescence (Fig. 1D); the pleura epithelium was also immunonegative and remained without $\mathrm{Na}^{+} / \mathrm{K}^{+}$-ATPase detection at the later stages. At PL9, positive immunoreactivity was intense in the epipodites and branchiostegites (Fig. 1E,F); in contrast, gills were still free of immunofluorescence staining whereas positive immunoreactivity in gills was observed in adults (Figure 2). Sections without the primary antibody used as negative controls showed no specific staining (data not shown).

As shown by optical microscopy, PL9 larvae possess all the potential osmoregulatory organs in the branchial chamber (i.e gills, epipodites and branchiostegites) (Fig. 3A) and display an adult hyper-hypo-osmoregulatory pattern (Pham et al, 2012). Given these facts, electron microscopy was carried out at this stage only. The structure of gill lamellae appeared well developed (Fig. 3B, C), constituted by a very thin epithelium, with scarce nuclei under the cuticle, and a central connective tissue. Large hemolymph lacunae were observed between the two tissues. Cells with the features of ionocytes were present in the epipodites and branchiostegites. The epipodites (Fig. 3D,E) were composed of two identical facing epithelia separated by a hemolymph lacuna maintened opened by pillar cells joining the two epithelia. Both epithelia were formed by cells with numerous mitochondria associated with infoldings of the basal membrane of the cell. Deep and abundant microvilli were located at the apical part of the cell under the thin cuticle. Typical ionocytes were also present in the internal 
epithelia of the branchiostegites (Fig. 3F,G) with pilar cells presenting apical microvilli as well as deep and abundant infoldings associated with mitochondria.

\subsection{Full-length cDNA cloning of $L s N K A$}

The entire cloned sequence of the LsNKA cDNA was characterized in this study and found to contain 3092 bp, with a 3036-bp open reading frame (ORF) and a 5'untranslated region of 56 bp (deposited under the Genbank accession number: JN561324) (Fig. 4). A BlastN analysis showed high-scoring matches (>97\%) to corresponding $\mathrm{Na}^{+} / \mathrm{K}^{+}$-ATPase $\alpha$-subunit cDNA sequences from other penaeids including Penaeus monodon (Genbank accession number : EF672699.1), Fenneropenaeus indicus (HM012803.1) and L. vannamei (AY140650.1). The deduced amino acid sequence encodes a putative 1011 amino-acid polypeptide with a predicted molecular mass of $112.3 \mathrm{kDa}$. A putative Kozak consensus sequence (5'-CAGCCATGG-3') was found around the likely start codon (indicated in bold) (Kozak, 1991). Hydrophobicity analyses subsequently performed using the TMpred program (http://www.ch.embnet.org/software/TMPRED_form.html) allowed the identification of 10 transmembrane domains, in agreement with the topology of $\mathrm{Na}^{+} / \mathrm{K}^{+}$-ATPase $\alpha$-subunits from other invertebrates such as the euryhaline shore crab Pachygrapsus marmoratus (Jayasundara et al., 2007). In addition, a scan of the putative sequence against the PROSITE database allowed the identification of an ATP binding site $\left(\mathrm{V}^{503}\right.$ MKGAPERIL ${ }^{512}$ ) (Horisberger et al., 1991) as well as a P-type ATPase phosphorylation site $\left(\mathrm{D}^{364} \mathrm{KTGTLT}^{370}\right.$ ) (Fagan \& Saier, 1994). Phylogenetic tree analyses revealed that the L. stylirostris $\mathrm{Na}^{+} / \mathrm{K}^{+}$-ATPase $\alpha$-subunit clustered with those from other invertebrate species (especially those characterized in other marine invertebrates) (Fig. 5).

\subsection{Tissue expression of $\mathrm{Na}^{+} / \mathrm{K}^{+}$-ATPase $\alpha$-subunit gene}

Quantitative real-time RT-PCR (qPCR) was subsequently performed to determine the relative abundance of $\mathrm{Na}^{+} / \mathrm{K}^{+}$-ATPase $\alpha$-subunit mRNA in different tissues of L. stylirostris. As shown in Fig. 6, the $\mathrm{Na}^{+} / \mathrm{K}^{+}$-ATPase $\alpha$-subunit transcripts were expressed in all tested tissues. However, the $\mathrm{Na}^{+} / \mathrm{K}^{+}$-ATPase $\alpha$-subunit mRNA abundance was about 2.5 -fold higher in the epipodites and gills than in any other tested tissues. No statistical difference in mRNA transcript levels was observed within the different tissues that constitute the gills (i.e. arthrobranchs and pleurobranchs) $(P>0.05)$. 


\subsection{Expression of $\mathrm{Na}^{+} / \mathrm{K}^{+}$-ATPase $\alpha$-subunit gene at various stages of development}

Whole shrimp at different stages of development (nauplius, zoea 2, mysis 2 and postlarvae 2) were analyzed for the expression of the $\mathrm{Na}^{+} / \mathrm{K}^{+}$-ATPase $\alpha$-subunit-encoding gene. The total RNA sample from shrimp at each stage was tested by qRT-PCR and the relative expression was calculated relatively to the mRNA level of the elongation factor $1-\alpha$ gene. The expression of this control gene has been demonstrated to remain statistically stable during larval development (data not shown). Expression of mRNA was detected in all measured samples (Fig. 7), with the highest levels at the nauplius and PL2 stages. However, no significant difference was observed between the different developmental stages during this study $(P>0.05)$.

\subsection{Functional study of the shrimp $\mathrm{Na}^{+} / \mathrm{K}^{+}$-ATPase $\alpha$-subunit gene}

An experiment was conducted to explore the functional role of $L s N K A$ in osmoregulation. In the course of this experiment, we first checked that LsNKA message was successfully downregulated using sequence-specific dsRNA. As determined by qPCR (Fig. 8), intramuscular injection of $L s N K A$ sequence-specific dsRNA resulted in a statistically significant depletion of cognate mRNA levels. Depletion was restricted to injection with dsRNA with no suppression of LsNKA expression occurring in control animals. As summarized in Fig. 9, the transfer of saline-injected control shrimp from $27 \mathrm{ppt}$ to different salinity levels $(5,27$ or $40 \mathrm{ppt})$ did not induce any significant increase in mortality $(P>0.05)$. Knock down of $L s N K A$ expression by dsRNA injection statistically affected the survival of animals transferred under isosmotic conditions (i.e. $27 \mathrm{ppt)}$ with a mortality of $18 \%$ after 48 hours (ANOVA, $P<0.05$ ). A transfer of shrimp injected with dsRNA from 27ppt to 5ppt and 40ppt increased the shrimp susceptibility and led to a mortality of $57 \%$ and $38 \%$, respectively which were significantly higher than mortalities in control groups with $0 \%$ and $3 \%$, respectively (ANOVA, $P<0.05$ ). 


\section{Discussion}

In species with a biphasic life cycle, such as L. stylirostris, L. vannamei, P. japonicus and C. crangon, osmoregulatory capabilities are linked to the occurrence of specialized osmoregulatory structures such as the pleura, branchiostegite, gills and epipodites (Bouaricha et al., 1994; Charmantier et al., 1988; Cieluch et al., 2004; review in Charmantier et al., 2009; Pham et al., 2012; Chong-Robles et al., 2014).

In zoeae, we identified the pleura as the unique site of $\mathrm{Na}^{+} / \mathrm{K}^{+}$-ATPase localization while the involvement of the branchiostegites in ion transport occurred from the mysis stages only, as indicated by the detection of $\mathrm{Na}^{+} / \mathrm{K}^{+}$-ATPase by immunostaining. We also reported here the abundance of ionocytes on epipodites, a category of cells known to be specialized for active ion transport (Taylor and Taylor, 1992), as well as a reduced involvement of the gills in the osmoregulation processes in L. stylirostris postlarvae, as indicated by the lack of positive staining in the gill filaments. These observations are supported by our data of TEM, no differentiated epithelia being detected in the gills of PL9 post-larvae, while ionocytes were found in branchiostegites and epipodites. In contrast, the positive immunostaining observed in gills of juveniles suggests a late implication of this tissue in osmoregulatory functions. In summary, our results evidenced a shift in the location of ion-transporting epithelia during post-embryonic development of L. stylirostris: osmoregulation occurs in the pleura and branchiostegites during the first larval stages (zoeae and mysis), while the osmoregulatory function shifts in the subsequent stages from the pleura to the epipodites and is accompanied by the acquisition of a hyper-hypo-osmoregulation pattern. Similar types of tissue differentiation and shifts of function have also been described in the few other peneids in which the development and localization of the osmoregulation sites have been investigated such as Penaeus aztacus (Talbot et al., 1972) or P. japonicus (Bouaricha et al., 1994), as well as in other decapod crustaceans, with some degree of variations in the chronology and location of the osmoregulatory sites. For instance, in the European lobster Homarus gammarus, the branchiostegites and epipodites have also been described as the main sites of osmoregulation, the gills being free of immunostaining (Flik and Haond, 2000; Lignot and Charmantier, 2001). In this species, the epipodites are already present in embryos and play an effective role in osmoregulation while the branchiostegites are involved after metamorphosis only. In the carid shrimp C. crangon and M. amazonicum, the branchiostegites participate to ionic exchange as early as in zoeae stages (Cieluch et al., 2005; Boudour-Boucheker et al., 2013). 
Our results show that the capacity to osmoregulate in L. stylirostris, progressively acquired during the larval development, and associated with an increasing tolerance to salinity variations (Pham et al., 2012), is linked to the progressive differentiation of different organs in the branchial cavity where $\mathrm{Na}^{+} / \mathrm{K}^{+}$-ATPase is detected. In postlarval stages, we found that the gills are probably not involved in osmoregulation, in contrast with other species such as the crayfish Astacus leptodactylus (Lignot et al., 2005) or brachyuran crabs like Carcinus maenas (Cieluch et al., 2004), in which the posterior gills are involved in osmoregulation while anterior gills are mainly devoted to respiratory functions.

To assess these findings, we attempted to characterize the gene encoding the sodium pump to provide more sensitive information regarding the pattern of ontogenetic regulation. We cloned and characterized a $\mathrm{Na}^{+} / \mathrm{K}^{+}$-ATPase $\alpha$-subunit homologue, $L s N K A$. The inferred amino acid sequence of $L s N K A$ cDNA revealed that the putative protein possesses the main structural characteristics of the $\mathrm{Na}^{+} / \mathrm{K}^{+}$-ATPase $\alpha$-subunits, i.e. 10 membrane-spanning helices as well as an ATP binding site and a P-type ATPase phosphorylation site, confirming the high conservation of $\mathrm{Na}^{+} / \mathrm{K}^{+}$-ATPase $\alpha$-subunits between species. A putative signal peptide cleavage site $\left(\mathrm{G}^{95} \mathrm{AILCF}{ }^{100}\right)$ was also identified within the first predicted transmembrane region, as described in other marine invertebrates (Lucu and Towle, 2003). When subtracting the amino acid residues located upstream of this putative cleavage site, the theoretical molecular mass was determined at $101 \mathrm{kDa}$, a value consistent with the apparent molecular weight estimated by Western blotting (Figure S1, supplementary data).

In vertebrates, the $\mathrm{Na}^{+} / \mathrm{K}^{+}$-ATPase $\alpha$-subunit has several isoforms differing in sensitivity to proteases, cross-linking agents or electrophoretic mobility for instance. Thus far, four $\alpha$ subunit isoforms have been identified in mammals (Mobasheri et al., 2000), while five and nine $\mathrm{Na}^{+} / \mathrm{K}^{+}$-ATPase $\alpha$-isoforms have been characterized in the rainbow trout Oncorhynchus mykiss and in the zebrafish Danio rerio, respectively (Rajarao et al., 2001; Richards et al., 2003). In the brine shrimp Artemia salina, two isoforms have been found and reported to be differentially expressed during early development (Peterson et al., 1978; Cortas et al., 1989). The sea urchin Hemicentrotus pulcherrimus possesses also two $\alpha$-subunit isoforms encoded by a single gene and produced by differential exon splicing (Yamazaki et al., 1997). In the present study, our experiments did not permit to identify additional isoforms or alternative splicing products among the different osmoregulatory organs of L. stylirostris. Whether or not $\alpha$-subunit cDNA variants can be found in this species remains therefore to be elucidated.

We also investigated the expression pattern of LsNKA in L. stylirostris tissues. LsNKA mRNA expressions were detected in all the studied tissues, as also reported in the shrimp 
Macrobrachium nipponense (Wang et al., 2003) but also in all the metazoans studied so far. The wide distribution of this enzyme may be linked to its known implication in other physiological processes such as cellular volume regulation or calcium absorption during ecdysis (Lucu and Towle, 2003).

As immunofluorescence had shown that branchial cavity organs are progressively involved in osmoregulation during ontogenesis, we next investigated the mRNA expression pattern of LsNKA. Our results demonstrate that this gene is constitutively expressed in all the studied stages, starting in nauplius. Similar data were reported in the crayfish Astacus leptodactylus demonstrating that the $\mathrm{Na}^{+} / \mathrm{K}^{+}$-ATPase $\alpha$-subunit gene was constitutively expressed in all the studied ontogenetic stages starting at the metanauplius stage (Serrano et al., 2007). However in our study, its expression level did not significantly vary afterwards, whereas our immunological results showed that the branchial cavity organs are progressively involved in osmoregulation process. Several hypotheses may explain this result. First, due to the size of the animals, mRNA expression was measured on whole larvae. And NKA expression relative to antennal glands and gut, which are others osmoregulatory organs in crustaceans (Mantel and Farmer, 1983) could have masked the differences detected in branchial cavity tissues with immunocytochemistry. Considering also the ubiquitous localization of this enzyme (including tissues not related to osmoregulation), we hypothesize that this procedure may have partially reduced variations of LsNKA gene expression between the different larval stages. Another explanation is that the sodium pump is considered to be a "housekeeping" protein involved in different signaling pathways via interaction with other proteins, e.g. in regulation of membrane trafficking and in the operation of cell junctions. Therefore we also hypothesize that the osmoregulatory capacity of L. stylirostris at different larval stages may not result from de novo synthesis of new enzyme (characterized by an increase in the abundance of the corresponding mRNA) but from activation of pre-existing enzyme. To date, information on the embryonic ontogeny of osmoregulation remains scarce in decapod crustaceans. Further studies are thus needed to determine whether or not transcript expression fits the $\mathrm{Na}^{+} / \mathrm{K}^{+}$-ATPase activity.

Finally to address the in vivo role of LsNKA in osmoregulation we developed a RNAi-based approach. Since its first description in nematodes (Fire et al., 1998), this reverse genetics approach has opened avenues for the study of candidate genes in most metazoan species, including crustaceans. For example, several studies have contributed to solve gene functions involved in immune response, molting, reproduction or glucose metabolism in shrimp (reviewed in Robalino et al., 2011). We have previously shown that in vivo gene silencing 
lasted for more than 4 days but less than eight, with maximum level of knockdown observed after 48 hours (de la Vega et al., 2008; Labreuche et al., 2009). First, we have shown that injection of $L s N K A$ sequence-specific dsRNA into shrimp induced a significant depletion of cognate mRNA levels. Then, we submitted the animals to an abrupt salinity change (from 27 ppt to 5 or $40 \mathrm{ppt}$ ). While the transfer of control (saline-injected) animals did not induce any significant mortality, we showed that $L s N K A$ silencing significantly increased the shrimp susceptibility to salinity changes: after transfer to 40 or 5 ppt respectively, mortality was 2 to 3 times higher in the $L s N K A$-knockdown animals than in $L s N K A$ dsRNA-injected group kept at $27 \mathrm{ppt}$. These results demonstrated the biological implication of this gene in ionic regulation process; they also indirectly confirmed the role of $\mathrm{Na}^{+} / \mathrm{K}^{+}$-ATPase in different signaling pathways since we observed mortalities in LsNKA-knockdown animals kept under isosmotic conditions.

This study brings further information towards understanding the mechanisms behind the osmoregulation processes that occur during the post-embryonic development of $L$. stylirostris. It is well known now that osmoregulation in crustaceans relies on the coordinated action of a suite of transport proteins and transport-related enzymes, including, among others, the V-Type ATPase, carbonic anhydrase (reviewed in Henry et al, 2012). We are currently developping efforts to identify and characterize other enzymes for future studies investigating the molecular bases of the physiological and evolutionary responses of L. stylirostris shrimp to osmoregulatory challenges in their estuarine environment. Such knowledge will greatly participate to improve growth under aquaculture conditions and set up better acclimatizing procedures in animals.

\section{Acknowledgments}

The authors are indebted to Dr Elizabeth Ficko-Blean for the critical review of this manuscript and her help in editing the English language. This work was supported by the DEDUCTION project funded by the Institut Français de Recherche pour l'Exploitation de la Mer (IFREMER), the Provincial Institutions (Province Sud, Province Nord and Province des Iles Loyauté) and by the Government of New Caledonia. Thanks are due to the zootechnical staff of the experimental hatchery of Saint-Vincent (F. Broutoi, J.R. Mailliez, J.M. Peignon) for their help in supplying L. stylirostris larvae and postlarvae. The authors also thank the "Plate-forme de Recherche pour les Sciences du Vivant de Nouvelle-Calédonie (PFV-NC)" 
for allowing access to the qPCR facility and the Electron Microscopy department in Université de Montpellier 2. Any opinions, findings, and conclusions or recommendations expressed in this material are those of the authors and do not necessarily reflect the views of the supporting bodies mentioned herein. 


\section{References}

Altschul, S.F., Madden T.L., Schäffer A.A., Zhang J., Zhang Z., Miller W., Lipman D.J., 1997. Gapped BLAST and PSI-BLAST: a new generation of protein database search programs. Nucleic Acids Res. 25 (17): 3389-402.

Bouaricha, N., Charmantier-Daures, M., Thuet, P., Trilles, J.-P. and Charmantier, G., 1994. Ontogeny of Osmoregulatory Structures in the Shrimp Penaeus japonicus (Crustacea, Decapoda). The Biological Bulletin, 186, ${ }^{\circ} 1: 29-40$.

Boudour-Boucheker, N., Boulo, V., Lorin-Nebel, C., Elguero, C., Grousset, E., Anger, K., Charmantier-Daures, M., Charmantier, G., 2013. Adaptation to freshwater in the palaemonid shrimp Macrobrachium amazonicum: comparative ontogeny of osmoregulatory organs. Cell Tissue Res. 353: 87-98.

Boudour-Boucheker, N., Boulo, V., Charmantier-Daures, M., Evelyse Grousset, E., Anger K., Charmantier, G., Lorin-Nebel, C., 2014. Differential distribution of V-type $\mathrm{H}^{+}$-ATPase and $\mathrm{Na}^{+} / \mathrm{K}^{+}$-ATPase in the branchial chamber of the palaemonid shrimp Macrobrachium amazonicum. Cell Tissue Res. 357, 195-206.

Castilho, P.C., Martins, I.A., and Bianchini, A., 2001. Gills $\mathrm{Na}^{+}, \mathrm{K}^{+}$-ATPase and osmoregulation in estuarine crab Chasmagnatus granulata Dana, 1851 (Decapoda, Grapsidae). J. Exp. Biol. Ecol. 256, 215-227.

Charmantier, G.,1986. Variation des capacités osmoregulatrices au cours du développement post-embryonnaire de Peaneus japonicus Bate, 1888 (Crustacea, Decapoda). C.R. Acad. Sci. Paris. 303, 217-222.

Charmantier, G., 1998. Ontogeny of osmoregulation in crustaceans: a review. Invert. Reprod. Develop. 33, 177-190.

Charmantier, G., Charmantier-Daures, M., Bouaricha, N., Thuet, P., Aiken D. E, Trilles, J.-P., 1988. Ontogeny of osmoregulation and salinity tolerance in two decapod crustaceans: Homarus americanus and Penaeus japonicus. Biol. Bull. 175, No. 1, 102-110. 
Charmantier, G., Haond, C., Lignot, .J. H., Charmantier-Daures, M., 2001. Ecophysiological adaptation to salinity throughout a life cycle: a review in homarid lobsters. J. Exp. Biol. 204, 967-977.

Charmantier, G., Charmantier-Daures, M., Towle, D., 2009. Osmotic and ionic regulation in aquatic arthropods. In "Osmotic and ionic regulation. Cells and animals", D. H. Evans, Ed., CRC Press, NewYork, NY, Oxford, UK, 165-230.

Chong-Robles, J., Charmantier, G., Boulo, V., Lizarraga-Valdez, J., Enriquez-Paredes, L.M., Giffard-Mena, I., 2014. Osmoregulation pattern and salinity tolerance of the white shrimp Litopenaeus vannamei (Boone, 1931) during post-embryonic development. Aquaculture 422423, 261-267.

Chung, K.-F., Lin, H.-C., 2006. Osmoregulation and Na,K-ATPase expression in osmoregulatory organs of Scylla paramamosain. Comp. Biochem. Physiol. Part A 144, 4857.

Cieluch, U., Charmantier, G., Grousset, E.,Charmantier-Daures, M., 2005. Osmoregulation, immunolocalization of $\mathrm{Na}^{+} / \mathrm{K}^{+}$-ATPase, and ultrastructure of branchial epithelia in the developing Brown Shrimp, Crangon crangon (Decapoda, Caridea). Physiol. Biochem. Zoo. 78(6), 1017-1025.

Cieluch, U., Anger, K., Aujoulat, F., Buchholz, F., Charmantier-Daures, M., Charmantier G., 2004. Ontogeny of osmoregulatory structures and functions in the green crab Carcinus maenas (Crustacea, Decapoda). J. Exp. Biol. 207, 325-336.

Cortas, N., Arnaout, M., Salon, J., Edelman, I.S., 1989. 1soforms of Na,K-ATPase in Artemia salina: II. Tissue Distribution and Kinetic Characterization. J. Membrane Biol. 108: 187-195.

de la Vega, E., O’Leary, N.A., Shockey, J.E., Robalino, J., Payne, C., Browdy, C.L., Warr, W.G., Gross, P.S., 2008. Antilipopolysaccharide factor in Litopenaeus vannamei (LvALF): a broad spectrum antimicrobial peptide essential for shrimp immunity against bacterial and fungal infection. Mol. Immunol. 45:1916-25. 
De Lorgeril, J., Gueguen, Y., Goarant,C., Goyard, E., Mugnier, C., Fievet, J., Piquemal, D., Bachère, E., 2008. A relationship between antimicrobial peptide gene expression and capacity of selected shrimp line to survive a Vibrio infection. Mol. Immunol. 45, 3438-3445.

Fagan, M.J., Saier, M.H. Jr., 1994. P-type ATPases of eukaryotes and bacteria: sequence analyses and construction of phylogenetic trees. J. Mol. Evol. 38:57-99.

Felsenstein, J., 1985. Confidence limits on phylogenies: An approach using the bootstrap. Evolution, 39: 783-791.

Fire, A., Xu, S.Q., Montgomery, M.K., Kostas, S.A., Driver, S.E., Mello, C.C., 1998. Potent and specific genetic interference by double-stranded RNA in Caenorhabditis elegans. Nature Vol. 391, 806-811.

Flik, G.,Haond, C., 2000. $\mathrm{Na}^{+}$and $\mathrm{Ca}^{2+}$ pumps in the gills, epipodites and branchiostegites of the European lobster Homarus gammarus : effects of dilute seawater. J. Exp. Biol. 203, 213220.

Henry, R.P., Lucu, C., Onken, H., Weihrauch, D., 2012. Multiple functions of the crustacean gill : osmotic/ionic regulation, acid-base balance, ammonia excretion, and bioaccumulation of toxic metals. Frontiers in Physiology. $3: 431$.

Horisberger, J.D., Lemas, V., Kraehenbühl, J.P., Rossier, B.C., 1991. Structure-function relationship of Na,K-ATPase. Annual Review of Physiology, 53: 565-84.

Jayasundara, N., Towle, D.W., Weihrauch, D., Spanings-Pierrot, C., 2007. Gill-specific transcriptional regulation of $\mathrm{Na}^{+} / \mathrm{K}^{+}$-ATPase alpha-subunit in the euryhaline shore crab Pachygrapsus marmoratus : sequence variants and promoter structure. J. Exp. Biol. 210 (Pt 12) : 2070-81.

Kozak, M., 1991. Structural features in eukaryotic mRNAs that modulate the initiation of translation. J. Biol. Chem. 266: 19867-19870. 
Labreuche, Y., O’Leary, N.A., de la Vega, E., Veloso, A., Gross, P.S., Chapman, R.W., 2009. Lack of evidence for Litopenaeus vannamei Toll receptor (IToll) involvement in activation of sequence-independent antiviral immunity in shrimp. Dev. Comp. Immunol. 33 : 806-10.

Labreuche, Y., Veloso, A., De La Vega, E., Gross, P.S., Chapman, R.W., Browdy, S.L., Warr, G.W., 2010. Non-specific activation of antiviral immunity and induction of RNA interference may engage the same pathway in the Pacific white leg shrimp Litopenaeus vannamei. Dev. Comp. Immunol. 34: 1209-1218.

Lignot, J.-H., Charmantier, G., 2001. Immunolocalization of $\mathrm{Na}^{+}, \mathrm{K}^{+}$-ATPase in the branchial cavity during the early development of the European lobster Homarus gammarus (Crustacea, Decapoda). J. Histochem. Cytochem. 49, 1013-1023.

Lucu, C., Towle, D.W., 2003. $\mathrm{Na}^{+}, \mathrm{K}^{+}$-ATPase in the gills of aquatic crustacea. J. Comp. Biochem. Physiol. 135 A, 195-214.

Lignot, J.-H., Nugroho Susanto, G., Charmantier-Daures, M., Charmantier, G., 2005. Immunolocalization of $\mathrm{Na}^{+} / \mathrm{K}^{+}$-ATPase in the branchial cavity during the early development of the crayfish Astacus leptodactylus (Crustacea, Decapoda). Cell. Tissue Res. 319, 331-339.

McNamara, J.C., Faria, S.C., 2012. Evolution of osmoregulatory patterns and gill ion transport mechanisms in the decapod crustacea: a Review. J. Comp. Physiol. B 182, 997 1014.

Mantel, L.H., Farmer, L.L., 1983. Osmotic and ionic regulation. In: Mantel, L. H. (Ed.), The Biology of Crustacea, vol. 5. Academic Press, New York, pp. 53-161.

Martinez, A-S., Charmantier, G., Compère, P., Charmantier-Daures, M., 2005. Branchial chamber tissues in two caridean shrimps: the epibenthic Palaemon adspersus and the deepsea hydrothermal Rimicaris exoculata. Tissue Cell 37: 153-165.

Mobasheri, A., Avila, J., Cozar-Castellano, I., Brownleader, M. D., Trevan, M., Francis, M. J., Lamb, J. F., Martin-Vasallo, P., 2000. Na+, K+-ATPase isozyme diversity; comparative 
biochemistry and physiological implications of novel functional interactions. Bioscience Rep. 20, 51-91.

O’Leary, N. A., Trent, H. F., III, Robalino, J., Peck, M.E.T., McKillen, D.J., Gross, P.S., 2006. Analysis of multiple tissue-specific cDNA libraries from the Pacific whiteleg shrimp, Litopenaeus vannamei. Integr. Comp. Biol. 46, 931-939.

Pfaffl, M.W., Horgan, G.W., Dempfle, L., 2002. Relative expression software tool (REST(C)) for group-wise comparison and statistical analysis of relative expression results in real-time PCR. Nucleic Acid Res. 30 (9), e36.

Péqueux, A., 1995. Osmotic regulation in crustaceans. J. Crust. Biol. 15 : 1-60.

Peterson, G.L., Edwing, R.D., Conte, F.P., 1978. Membrane differenciation and de nova synthesis of the $\left(\mathrm{Na}^{+} \mathrm{K}^{+}\right)$-activated adenosine triphosphate during development of Artemia salina nauplii. Dev. Biol. 67: 90-98.

Pham, D., Charmantier, G., Wabete, N., Boulo, V., Broutoi, F., Mailliez, J.-R., Peignon, J.M., Charmantier-Daures, M., 2012. Salinity tolerance, ontogeny of osmoregulation and zootechnical improvement in the larval rearing of the Caledonian blue shrimp, Litopenaeus stylirostris (Decapoda, Penaeidae). Aquaculture 362-363, 10-17.

Rajarao, S. J., Canfield, V. A., Mohideen, M. A., Yan, Y. L., Postlethwait,J. H., Cheng, K. C., Levenson, R., 2001. The repertoire of Na,KATPase $\alpha$ and $\beta$ subunit genes expressed in the zebrafish, Danio rerio. Genome Res. 11, 1211-1220.

Richards, J. G., Semple, J.W., Bystriansky, J.S., Schulte, P.M., 2003. Na ${ }^{+} / \mathrm{K}^{+}-$ATPase $\alpha-$ isoform switching in gills of rainbow trout (Oncorhynchus mykiss) during salinity transfer. J. Exp. Bio. 206 : $4475-4486$.

Robalino, J., Chapman, R.W., de la Vega, E., O'Leary, N.A., Gorbach, D.M., Du, Z.-Q., Rothschild, M.F., Browdy, C.L., Warr, G.W., Labreuche, Y., 2011. Advances in genomics and genetics of Penaeid Shrimp, in aquaculture biotechnology (eds G. L. Fletcher and M. L. Rise), Wiley-Blackwell, Oxford, UK. 
Saitou, N., Nei, M., 1987. The neighbor-joining method: A new method for reconstructing phylogenetic trees. Mol. Biol. Evol. 4 : 406-425.

Serrano, L., Towle, D.W., Charmantier, G., Spanings-Pierrot, C., 2007. Expression of $\mathrm{Na}^{+} / \mathrm{K}^{+}$-ATPase $\alpha$-subunit mRNA during embryonic development of the crayfish Astacus leptodactylus. Comp. Biochem. Physiol. Part D 2, 126-134.

Talbot, P., Clark, W.H., Lawrence, A.L., 1972. Light and electron microscopic studies on osmoregulatory tissue in the developing brown shrimp, Penaeus aztecus. Tissue Cell 4, $271-$ 286.Tamura, K., Dudley, J., Nei, M., Kumar, S., 2007. MEGA4: Molecular Evolutionary Genetics Analysis (MEGA) software version 4.0. Mol. Biol. Evol. 24 : 1596-1599.

Taylor, H.H., Taylor, E.W., 1992. Gills and lungs: The exchange of gases and ions. In: Harrison, F.W., Humes, A.G. (Eds.), Microscopic Anatomy of Invertebrates. Vol 10. Decapod Crustacea. Wiley-Liss, New York : 203-293.

Toyoshima, C., Kanai, R., Cornelius, F., 2011. First crystal structures of Na+,K+-ATPase: new light on the oldest ion pump. Structure, 19(12):1732-8.

Wang,W.-N., Wang, A.-L.,Wanga, D.-M.,Wanga, L.-P., Liua, Y., Sun, R.-Y., 2003. Calcium, phosphorus and adenylate levels and $\mathrm{Na}^{+}-\mathrm{K}^{+}$-ATPase activities of prawn, Macrobrachium nipponense, during the moult cycle. Comp. Biochem. Physiol. Part A : 297-305.

Weihrauch, D., Ziegler, A., Siebers, D., Towle, D.W., 2001. Molecular characterization of Vtype $\mathrm{H}(+)$-ATPase ( $\beta$-subunit) in gills of euryhaline crabs and its physiological role in osmoregulatory ion uptake. J. Exp. Biol. 204, 25-37.

Weppe, M., Bonami, J.R., Lightner, D.V., 1992. Demostration de altas cualidades de la cepa de P. stylirostris AQUACOP SPR 43 resistente al virus IHHN. Memorias Congreso Ecuatoriano Acuicultura, pp 229-232. 
Wheatly, M.G., Henry, R.P., 1987. Branchial and antennal gland $\mathrm{Na}^{+} / \mathrm{K}^{+}$-dependent ATPase and carbonic anhydrase activity during salinity acclimation of the euryhaline crayfish Pacifastacus leniusculus. J. Exp. Biol. 133, 73-86.

Yamazaki, K., Okamura, C., Ihara, T. and Yasumasu, I., 1997. Two types of Na+-K+-ATPase alpha subunit gene transcript in embryos of the sea urchin, Hemicentrotus pulcherrimus. Zool. Sci. 14, 469-473. 


\section{Figure captions}

Figure 1. Immunolocalization of $\mathrm{Na}^{+}, \mathrm{K}^{+}$-ATPase in organs of the branchial cavity in $L$. stylrostris. A: Zoea 2. Transverse section of cephalothorax. Positive immunostaining along the pleura epithelium. B: Mysis 2. Transverse section of cephalothorax. Positive immunostaining in the epithelia of the pleura and branchiostegite. C: PL1. Transverse section of cephalothorax. Pleura, branchiostegite and the developing epipodites are immmunopositive. D: PL4. Transverse section of cephalothorax. Positive immunoreactivity in epipodites and branchiostegite while gills are negative. E: PL9. Fully developed epipodites are positive and gills are still negative. F: PL9. Strong immunopositive response in the pillar cells of the branchiostegite.

$\mathrm{BC}$ : branchial cavity; $\mathrm{Br}$ : branchiostegite; GB : gill bud; Ep : epipodite; GF : gill filament; He : Hepatopancreas; Pl : pleura. Bars $=100 \mu \mathrm{m}$.

Figure 2. Positive immunostaining of $\mathrm{Na}^{+}, \mathrm{K}^{+}$-ATPase in longitudinal section of gill filaments in L. stylirostris adults (25g). GF : gill filament. Bar $=50 \mu \mathrm{m}$.

Figure 3. Semi-thin section and ultrastructure of branchial organs from L. stylrostris at PL9 stage (P25 at $\left.29^{\circ} \mathrm{C}\right)$. A. Semi-thin section of the branchial cavity. B, C. Gill filament with its thin epithelia. D,E. Two views of the epipodite cells with their extensive network of apical microvilli. F. External part of the branchiostegite; note the thick cuticle and the deep basolateral infoldings. G. Internal part of the branchiostegite with numerous microvillae under a thin cuticle. Bars $=8 \mu \mathrm{m}($ except A bar $=20 \mu \mathrm{m})$.

BI: basolateral infoldings; $\mathrm{Br}$ : Branchiostegite; CCT: central connective tissue; $\mathrm{Cu}$ : cuticle; Ep: Epipodite; Epi: epithelia; Gf: gill filament; HL: hemolymp lacunae; Mi: mitochondrium; Mv: microvilli; Nu: nucleus.

Figure 4. Complete nucleotide sequence and predicted amino acid sequence of the $\mathrm{Na}^{+} / \mathrm{K}^{+}$ATPase $\alpha$-subunit cDNA amplified from L. stylirostris. The P-type ATPase motif is indicated by a yellow box, the likely ATPase binding site is symbolised by a solid red line. Predicted transmembrane domains are indicated in a gray background. The start and stop codons are indicated by bold lettering. 
Figure 5. Phylogenetic analysis of amino acid sequences of $\mathrm{Na}^{+} / \mathrm{K}^{+}$-ATPase $\alpha$-subunits from organisms representing different taxa. Multiple alignments were created and curated in MEGA 5.0. The tree was built using a Neighbor-joining method (Saitou \& Nei, 1987) and is drawn to scale, with branch lengths in the same units as those of the evolutionary distances used to infer the tree. Percentages of bootstrapping branch corrections are shown beside the branches. GenBank accession number are indicated between brackets.

Figure 6. $\mathrm{Na}^{+} / \mathrm{K}^{+}$-ATPase $\alpha$-subunit mRNA transcript abundance in L. stylirostris shrimp tissues. Expression values determined by quantitative real-time qPCR are presented as relative abundance in relation to the elongation factor 1-alphagene (EF1, accession no. AY117542.1). Bars represent \pm standard error of the mean. Different letters indicate statistically significant differences among the results $(P<0.05)$.

Ey : eyestalk; Hp : hepatopancreas; AB : arthrobranchs; PLB : pleurobranchs; E : epipodites; $\mathrm{Pl}$ : pleopods; $\mathrm{Mu}$ : abdominal muscle.

Figure 7. $\mathrm{Na}^{+} / \mathrm{K}^{+}$-ATPase $\alpha$-subunit mRNA transcript abundance at different stages of the larval development of L. stylirostris shrimp. Expression values determined by quantitative real-time qPCR are presented as relative abundance in relation to EF1 gene. Bars represent \pm standard error of the mean. Different letters indicate statistically significant differences among the results $(P<0.05)$.

Figure 8. $L s N K A$ transcript abundance in shrimp gills following treatment with dsRNA. Shrimp were injected on day 0 with saline (Control) or with $10 \mu \mathrm{g}$ of $L s N K A$ dsRNA. At $48 \mathrm{~h}$ after this initial injection, 10 animals were randomly sampled in each group. Expression values determined by quantitative real-time qPCR are presented as relative abundance in relation to EF1 gene. Bars represent \pm standard error of the mean.

Figure 9. Shrimp mortality following injection with $L s N K A$ dsRNA and exposition to different salinities $(5,27$ or $40 \mathrm{ppt})$. Shrimps $(n=240)$ were injected intramuscularly with either saline or $L s N K A$ dsRNA. At $48 \mathrm{~h}$ after this initial injection, animals were transferred to seawater tanks at different salinities $(5,27$ or $40 \mathrm{ppt})$. This experiment was conducted in triplicate with 10 shrimps per tank. One-way analysis of variance was used to detect the differences in survival rates after data $\operatorname{arc} \sin (\sqrt{ })$ transformation. Student's $t$-tests were used to 
resolve differences among treatment means with $\alpha=0.05$. Different lower-case letters indicate significant difference between treatments $(\mathrm{P}<0.05)$.

\section{Tables}

Table 1. List of primers used in this study

Primer name

Sequence ( $\left.5^{\prime}-3^{\prime}\right)$

\section{PCR primers}

A-119

A-120

A-122

A-132
TGT ATC CTC TGC TGC CGT CCT

ACC CCA CCC AAG CAG ACT C

TGT TGC GTG CAC GCC AGC CC

ATA GTA GGT CTC CAG TTC CAT C

\section{qRT-PCR primers \\ target gene}

A-52

A-53

A-133

A-134
EF1

$\mathrm{EF} 1$

$\mathrm{NA}^{+} / \mathrm{K}^{+}$ATPase

$\mathrm{NA}^{+} / \mathrm{K}^{+}$ATPase
TGC TCA CAT TGC CTG CAA GT

CCT TAC CAG TAC GCC TGT CGA T

TCC CAT CCT GAA ACG TGA AGT AA

CTA CAC ACT TCA GCA GAG CAG CTT

Table 2 : Localization of the $\mathrm{Na}^{+/} \mathrm{K}^{+}$ATPase activity in the organs of the branchial cavity during the larval and postlarval development of Litopenaeus stylisrostris. $\mathrm{N}$ : absence of organ; + : positive fluorescence immunolocalization; - : negative fluorescence immunolocalization.

\begin{tabular}{|l|c|c|c|c|}
\hline Stage & Pleura & Branchiostegite & Epipodite & Gills \\
\hline Zoea 2 & + & - & $\mathrm{N}$ & $\mathrm{N}$ \\
\hline Mysis 2 & + & + & $\mathrm{N}$ & $\mathrm{N}$ \\
\hline PL1 & + & + & + & - \\
\hline PL2 & - & + & + & - \\
\hline PL4 & - & + & + & - \\
\hline PL9 & - & + & + & - \\
\hline
\end{tabular}




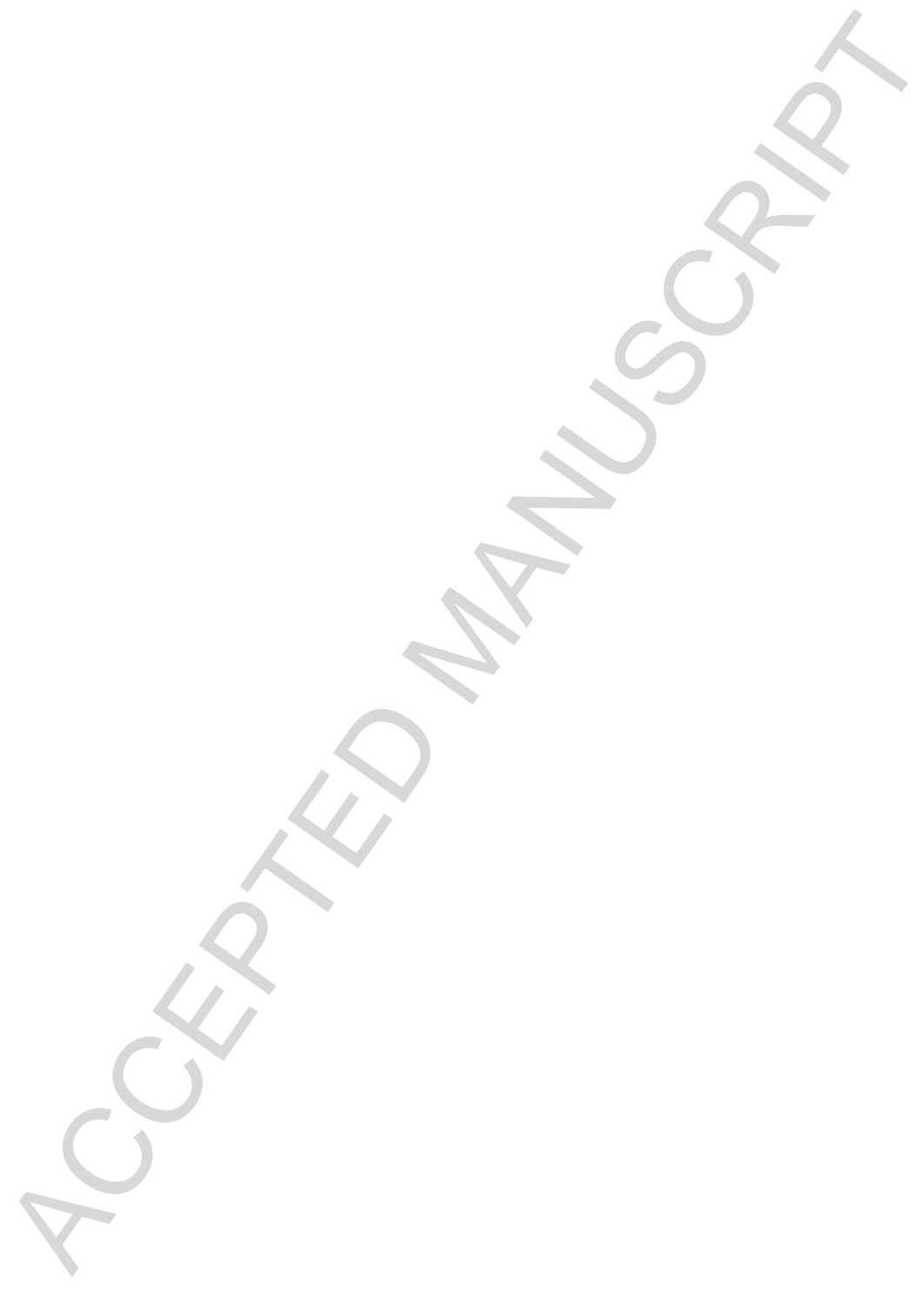


Fig 1
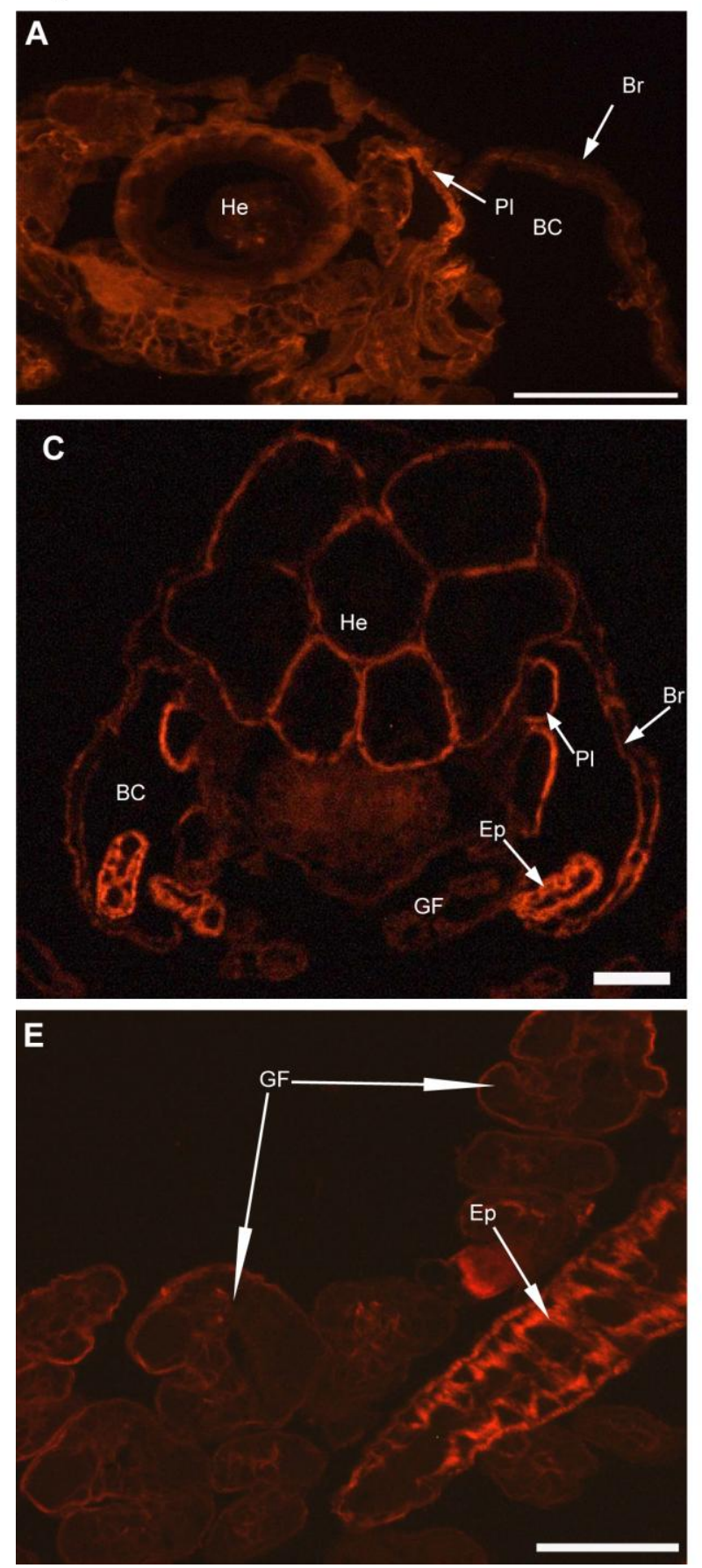
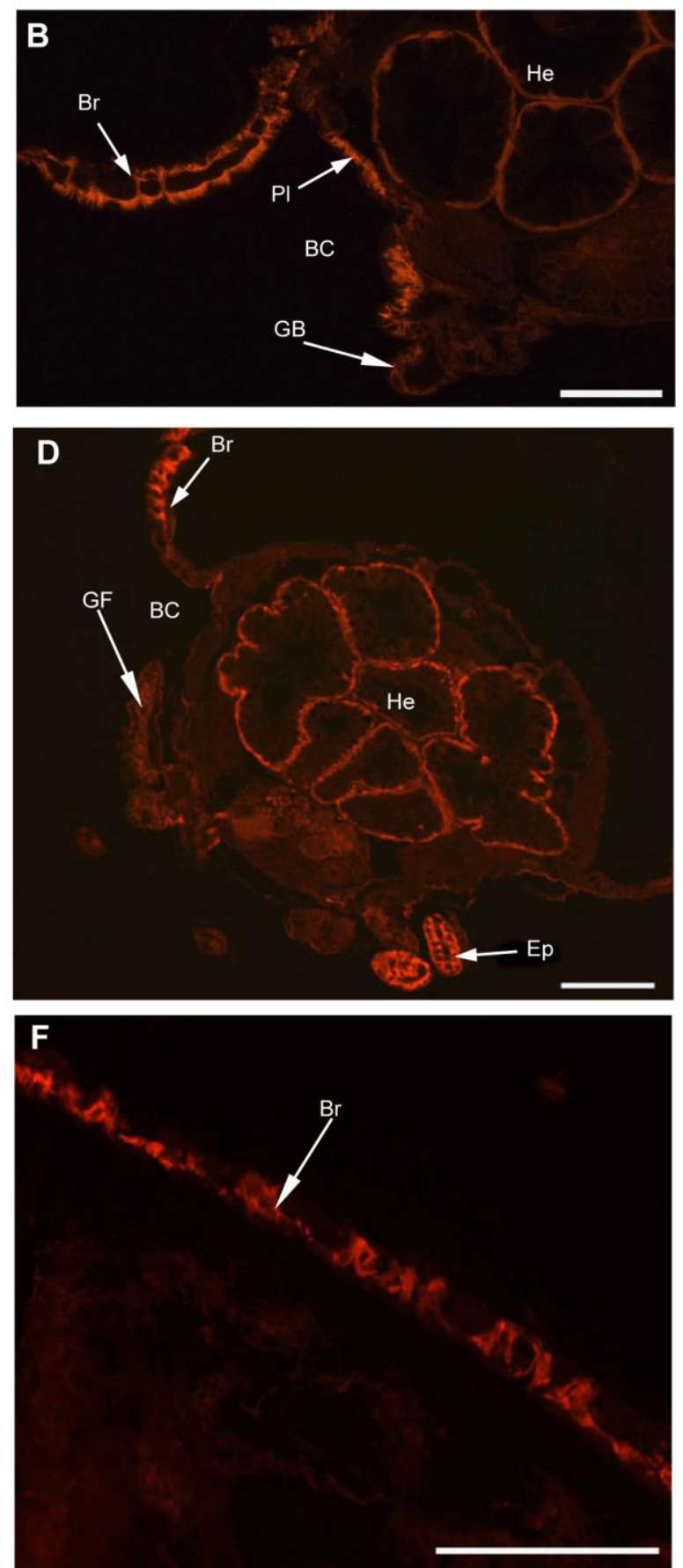
Fig. 2
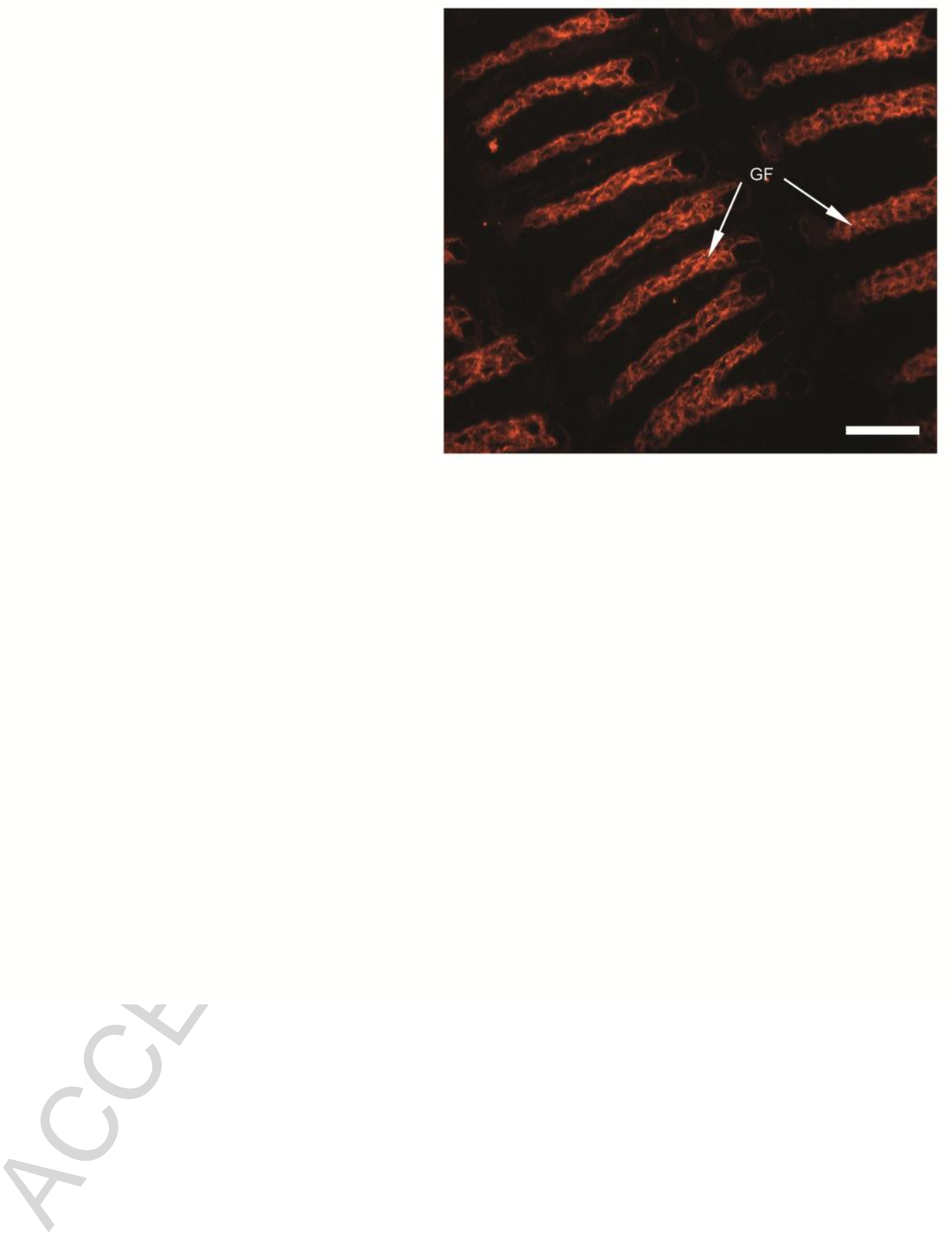
Fig. 3
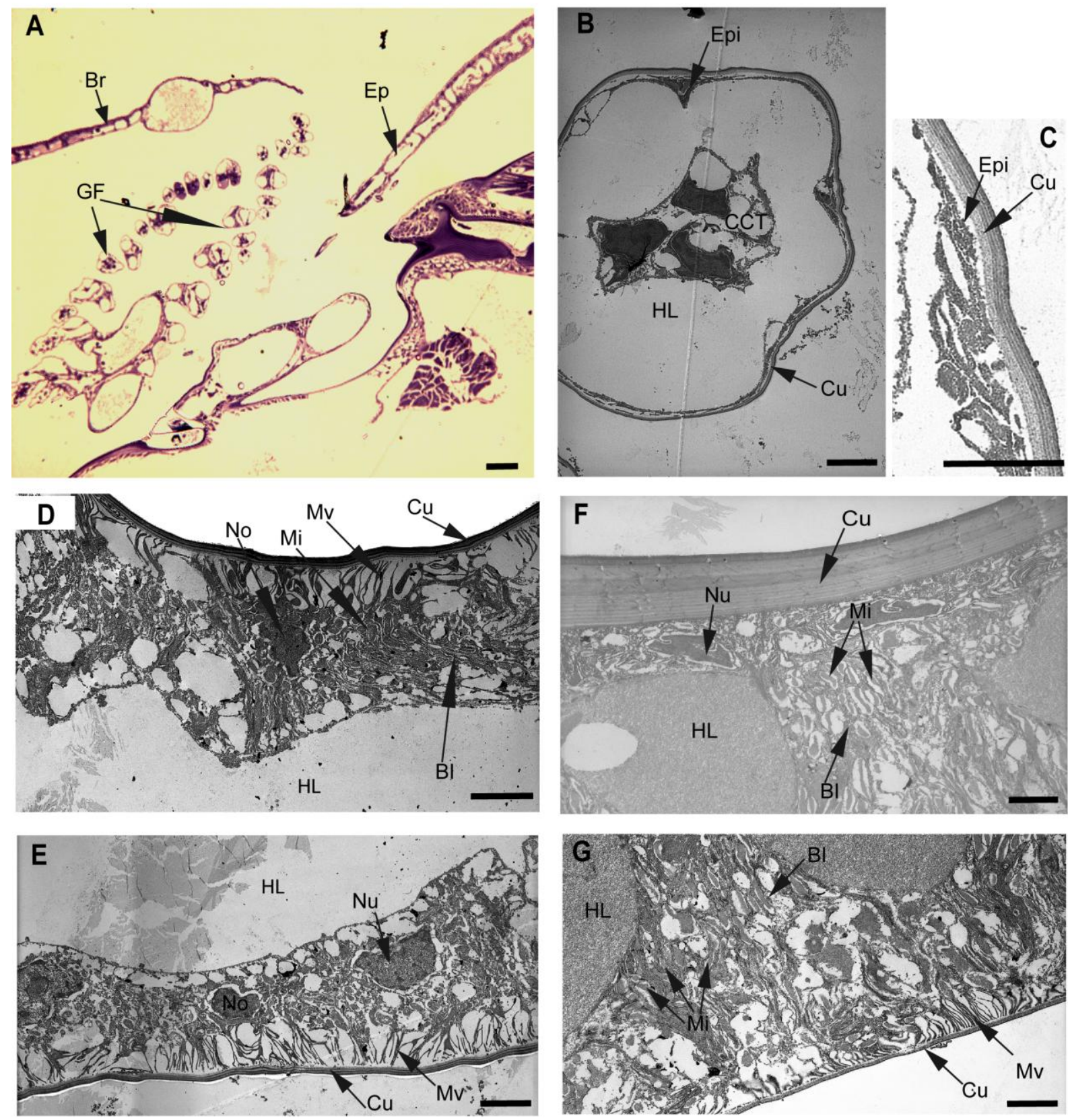


\section{Figure 4}

1 TGTaTCCTCTGCTGCCGTCCTCCTGCtGAGCGCCGAGTGTCGCCTCTTCAGCAGCCATGGCCGATTCTAAGAAAAAGCCC 80 $\begin{array}{llllllllllllllllllllllllllllllll}1 & \mathrm{Y} & \mathrm{P} & \mathrm{L} & \mathrm{L} & \mathrm{P} & \mathrm{S} & \mathrm{S} & \mathrm{C} & & * & \mathrm{~A} & \mathrm{P} & \mathrm{S} & \mathrm{V} & \mathrm{A} & \mathrm{S} & \mathrm{S} & \mathrm{A} & \mathrm{A} & \mathbf{M} & \mathrm{A} & \mathrm{D} & \mathrm{S} & \mathrm{K} & \mathrm{K} & \mathrm{K} & \mathrm{P} & 17\end{array}$

81 CAGAAGGCTAAAGGGAAAAGGGAGATAAGGATTTGAATGATCTGAAGCAGGAGTTGGAACTTGATGAGCACAAGGTCCC $\begin{array}{llllllllllllllllllllllllllllll}18 & Q & K & A & K & G & K & K & G & D & K & D & L & N & D & L & K & Q & E & L & E & L & D & E & H & K & V & P & 44\end{array}$ 161 AATTGAGGAACTCTTTCAACGTCTCACTGTTAACCCAGACACAGGTCTATCACAAAGTGAGGCTAAGCGCCGTATTGAAC $\begin{array}{llllllllllllllllllllllllllllll}45 & I & E & E & L & F & Q & R & L & T & V & N & P & D & T & G & L & S & Q & S & E & A & K & R & R & I & E & R & 71\end{array}$ 241 GAGATGGGCCGAACGCTCTTACCCCACCCAAGCAGACTCCAGAATGGGTCAAGTTCTGCAAAAACCTCTTCGGTGGTTTC $\begin{array}{llllllllllllllllllllllllllllll}72 & D & G & P & N & A & \text { L } & \text { T } & P & P & K & \mathcal{C} & \text { T } & \text { P } & \text { E } & \text { W } & \text { V } & \text { K } & \text { F } & \text { C } & \text { K } & \text { N } & \text { L } & \text { F } & \text { G } & \text { G } & \text { F } & 97\end{array}$ 321 TCACTCCTGCTGTGGATTGGCGCTATCCTCTGCTTCATTGCCTACTCAATTGAGACAGCTGCAGAAGAGGAGCCCAACAA

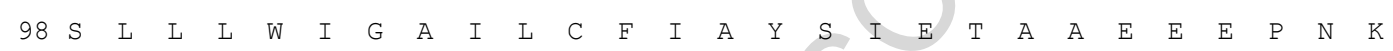
401 GGACAATTTGTACCTGGGCATTGTGCTCACAGCTGTCGTGATCATCACAGGCGTCTTCTCATATTACCAAGAAAGCAAGA $\begin{array}{lllllllllllllllllllllllllllll}125 & D & N & \text { L } & \text { Y } & \text { L } & G & \text { I } & \text { V } & \text { L } & \text { T } & \text { A } & \text { V } & \text { V } & \text { I } & \text { I } & \text { T } & G & \text { V } & \text { F } & \text { S } & \text { Y } & \text { Y } & \text { Q } & \text { E } & \text { S } & \text { K } & \text { S }\end{array}$ 481 GCTCCCGTATTATGGAATCTTTCAAGAACATGGTCCCTCAGTATGCTATTGTTCTTCGAGATGGCGAGAAGCAGAATGTT $\begin{array}{llllllllllllllllllllllllllll}152 & S & R & I & M & E & S & F & K & N & M & V & P & Q & Y & A & I & V & L & R & D & G & E & K & Q & N & V\end{array}$ 561 CAGGCTGAGGAACTGTGCATAGGAGACATTGTAGAGGTCAAGTTTGGTGATCGTATCCCAGCTGATATCCGTGTCATCGA $\begin{array}{llllllllllllllllllllllllllll}178 & Q & A & E & E & L & C & I & G & D & I & V & E & V & K & F & G & D & R & I & P & A & D & I & R & V & I & E\end{array}$ 641 AAGCAGGGGCTTCAAGGTTGACAACTCTTCCCTGACTGGAGAATCCGAACCCCAGAGCCGATCACCCGAATACACTTCCG $\begin{array}{lllllllllllllllllllllllllllll}205 & S & R & G & F & K & V & D & N & S & S & L & T & G & E & S & E & P & Q & S & R & S & P & E & Y & T & S & E\end{array}$ 721 AgAACCCCCTTGAGACCAAGAACTTGGCTTTCTTCTCCACCAATGCTGTCGAGGGTACTTGCAAGGGTATCGTTATCATG $\begin{array}{lllllllllllllllllllllllllll}232 & N & P & L & E & T & K & N & L & A & F & F & S & T & N & A & V & E & G & T & C & K & G & I & V & I & M\end{array}$ 801 ATTGGTGACAACACTGTGATGGGTCGTATTGCTGGTTTGGCATCCGGATTGGAAACTGGTGAAACCCCCATTGCCAAGGA $\begin{array}{lllllllllllllllllllllllllllll}258 & I & G & D & N & T & V & M & G & R & I & A & G & L & A & S & G & L & E & T & G & E & T & P & I & A & K & E\end{array}$ 881 AATTACCCATTTCATTCACATCATTACTGGTGTGGCTGTGTTCTTGGGTGTGACCTTCTTCGTTATTGCCTTCATCCTTG

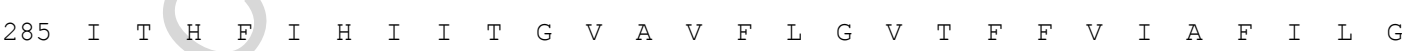
961 GGTACCATTGGTTGGATGCTGTTGTGTTCCTCATTGGTATCATTGTAGCCAATGTGCCTGAGGGTCTGCTAGCCACTGTC $\begin{array}{lllllllllllllllllllllllllllll}312 & \text { Y } & \text { H } & \text { W } & \text { L } & \text { D } & \text { A } & \text { V } & \text { V } & \text { F } & \text { L } & \text { I } & G & \text { I } & \text { I } & \text { V } & \text { A } & \text { N } & \text { V } & \text { P } & \text { E } & \text { G } & \text { L } & \text { L } & \text { A } & \text { T } & \text { V }\end{array}$

1041 ACTGTGTGCTTGACTCTTACTGCCAAGCGCATGGCTGCCAAGAACTGCCTTGTAAAGAACTTGGAGGCTGTGGAAACCCT $\begin{array}{lllllllllllllllllllllllllllll}338 & \mathrm{~T} & \mathrm{~V} & \mathrm{C} & \mathrm{L} & \mathrm{T} & \mathrm{L} & \mathrm{T} & \mathrm{A} & \mathrm{K} & \mathrm{R} & \mathrm{M} & \mathrm{A} & \mathrm{A} & \mathrm{K} & \mathrm{N} & \mathrm{C} & \mathrm{L} & \mathrm{V} & \mathrm{K} & \mathrm{N} & \mathrm{L} & \mathrm{E} & \mathrm{A} & \mathrm{V} & \mathrm{E} & \mathrm{T} & \mathrm{L}\end{array}$ 1121 GGGTTCCACTTCCACCATTTGCTCTGATAAGACTGGTACCCTCACCCAGAATCGTATGACAGTAGCACATATGTGGTTCG

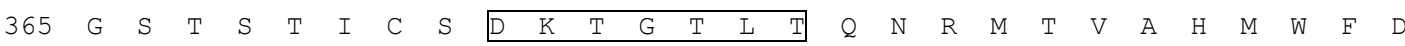
1201 ACAATACCATCATTGAAGCTGATACATCTGAAGATCAGTCTGGCTGCCAGTATGACAAGACCTCACAAGGCTGGAAGGCT $\begin{array}{lllllllllllllllllllllllllll}392 & \mathrm{~N} & \mathrm{~T} & \mathrm{I} & \mathrm{I} & \mathrm{E} & \mathrm{A} & \mathrm{D} & \mathrm{T} & \mathrm{S} & \mathrm{E} & \mathrm{D} & \mathrm{Q} & \mathrm{S} & \mathrm{G} & \mathrm{C} & \mathrm{Q} & \mathrm{Y} & \mathrm{D} & \mathrm{K} & \mathrm{T} & \mathrm{S} & \mathrm{Q} & \mathrm{G} & \mathrm{W} & \mathrm{K} & \mathrm{A}\end{array}$

1281 CTGTCTAGAATTGCTGCCCTCTGTAACCGTGCTGAATTCAAGACTGGTATGGAAAACACTCCCATCCTGAAACGTGAAGT $\begin{array}{lllllllllllllllllllllllllllll}418 & \text { L } & \mathrm{S} & \mathrm{R} & \mathrm{I} & \mathrm{A} & \mathrm{A} & \mathrm{L} & \mathrm{C} & \mathrm{N} & \mathrm{R} & \mathrm{A} & \mathrm{E} & \mathrm{F} & \mathrm{K} & \mathrm{T} & \mathrm{G} & \mathrm{M} & \mathrm{E} & \mathrm{N} & \mathrm{T} & \mathrm{P} & \mathrm{I} & \mathrm{L} & \mathrm{K} & \mathrm{R} & \mathrm{E} & \mathrm{V}\end{array}$

1361 AAACGGCGATGCTTCTGAAGCTGCTCTGCTGAAGTGTGTAGAATTGGCTGTTGGTGATGTTAAGGGCTGGCGTGCACGCA 
1520

1441 ACAAGAAGGTATGTGAAATTCCTTTCAACTCCACCAACAAGTACCAAGTATCCATCCACGAGACCGAGGATAAGAACGAC $\begin{array}{llllllllllllllllllllllllllll}472 & K & K & V & C & E & I & P & F & N & S & T & N & K & Y & Q & V & S & I & H & E & T & E & D & K & N & D\end{array}$

1521 CCACGATACCTTGTTGTGATGAAGGGAGCCCCTGAGAGGATCCTGGAACGTTGCTCCACCATCTACATCAATGGAGAGGA $\begin{array}{lllllllllllllllllllllllllllllllllll}498 & \text { P } & R & Y & L & V & V & M & K & G & A & P & E & R & I & L & E & R & C & S & T & I & Y & I & N & G & E & E\end{array}$

1601 AAAGGCCCTCGACGAAGAAATGAAGGAAGCTTTCAACAATGCCTACCTTGAATTGGGCGGTCTTGGAGAGCGTGTACTTG $\begin{array}{llllllllllllllllllllllllllllllll}525 & \text { K } & \text { A } & \text { L } & \text { D } & \text { E } & \text { E } & \text { M } & \text { K } & \text { E } & \text { A } & \text { F } & \text { N } & \text { N } & \text { A } & \text { Y } & \text { L } & \text { E } & \text { L } & \text { G } & \text { G } & \text { L } & \text { G } & \text { E } & \text { R } & \text { V } & \text { L } & \text { G }\end{array}$

1681 GTTTCTGTGACTACATGCTGCCAACTGACAAGTACCCTCTTGGATACCCCTTCGATGCTGATGCTGTGAACTTCCCTGTC $\begin{array}{lllllllllllllllllllllllllllll}552 & \text { F } & \text { C } & \text { D } & \text { Y } & \text { M } & \text { L } & \text { P } & \text { T } & \text { D } & \text { K } & \text { Y } & \text { P } & \text { L } & \text { G } & \text { Y } & \text { P } & \text { F } & \text { D } & \text { A } & \text { D } & \text { A } & \text { V } & \text { N } & \text { F } & \text { P } & \text { V }\end{array}$

1761 CATGGTCTGCGCTTCGTTGGTCTGATGTCCATGATTGATCCTCCTCGTGCTGCTGTACCCGATGCTGTAGCAAAgTGCAG $\begin{array}{lllllllllllllllllllllllllllll}578 & H & G & L & R & F & V & G & \text { L } & \text { M } & \text { S } & \text { M } & \text { I } & \text { D } & \text { P } & \text { P } & \text { R } & \text { A } & \text { A } & \text { V } & \text { P } & \text { D } & \text { A } & \text { V } & \text { A } & \text { K } & \text { C } & R\end{array}$

1841 ATCTGCTGGTATCAAGGTTATCATGGTTACTGGTGATCACCCCATCACTGCCAAGGCTATTGCCAAGTCTGTAGGTATCA $\begin{array}{llllllllllllllllllllllllllll}605 & \mathrm{~S} & \mathrm{~A} & \mathrm{G} & \mathrm{I} & \mathrm{K} & \mathrm{V} & \mathrm{I} & \mathrm{M} & \mathrm{V} & \mathrm{T} & \mathrm{G} & \mathrm{D} & \mathrm{H} & \mathrm{P} & \mathrm{I} & \mathrm{T} & \mathrm{A} & \mathrm{K} & \mathrm{A} & \mathrm{I} & \mathrm{A} & \mathrm{K} & \mathrm{S} & \mathrm{V} & \mathrm{G} & \mathrm{I} & \mathrm{I}\end{array}$

1921 TCTCTGAAGGAAACGAGACTGTTGAGGACATTGCACAGAGGTTGAACATTCCCATCAAGGAGGTCGACCCCACTGAAGCA $\begin{array}{llllllllllllllllllllllllllll}632 & S & E & G & N & E & T & V & E & D & I & A & Q & R & L & N & I & P & I & K & E & V & D & P & T & E & A\end{array}$

2001 AAGGCTGCTGTAGTTCACGGTTCTGAACTTCGTGACATGACATCCGAGCAGTTGGATGATGTCCTCCTCCACCACACTGA $\begin{array}{llllllllllllllllllllllllllllllllll}658 & \mathrm{~K} & \mathrm{~A} & \mathrm{~A} & \mathrm{~V} & \mathrm{~V} & \mathrm{H} & \mathrm{G} & \mathrm{S} & \mathrm{E} & \mathrm{L} & \mathrm{R} & \mathrm{D} & \mathrm{M} & \mathrm{T} & \mathrm{S} & \mathrm{E} & \mathrm{Q} & \mathrm{L} & \mathrm{D} & \mathrm{D} & \mathrm{V} & \mathrm{L} & \mathrm{L} & \mathrm{H} & \mathrm{H} & \mathrm{T} & \mathrm{E}\end{array}$

2081 AATCGTGTTTGCCCGTACCTCCCCACAACAGAAGCTGATCATTGTAGAAGGTTGCCAGCGTATGGGTGCCATTGTGGCTG $\begin{array}{llllllllllllllllllllllllllllll}685 & \text { I } & V & F & A & R & T & S & P & Q & Q & K & L & I & I & V & E & G & C & Q & R & M & G & A & I & V & A & V\end{array}$ 2161 TAACTGGTGATGGTGTGAATGATTCTCCTGCTCTGAAGAAGGCTGATATTGGTGTTGCTATGGGTATTGCTGGTTCTGAT $\begin{array}{llllllllllllllllllllllllllll}712 & T & G & D & G & V & N & D & S & P & A & L & K & K & A & D & I & G & V & A & M & G & I & A & G & S & D\end{array}$

2241 GTGTCCAAGCAAGCTGCTGACATGATTCTGTTGGACGACAACTTTGCTTCCATTGTCACCGGTGTTGAAGAGGGCAGACT $\begin{array}{llllllllllllllllllllllllllll}738 & \mathrm{~V} & \mathrm{~S} & \mathrm{~K} & \mathrm{Q} & \mathrm{A} & \mathrm{A} & \mathrm{D} & \mathrm{M} & \mathrm{I} & \mathrm{L} & \mathrm{L} & \mathrm{D} & \mathrm{D} & \mathrm{N} & \mathrm{F} & \mathrm{A} & \mathrm{S} & \mathrm{I} & \mathrm{V} & \mathrm{T} & \mathrm{G} & \mathrm{V} & \mathrm{E} & \mathrm{E} & \mathrm{G} & \mathrm{R} & \mathrm{L}\end{array}$

2321 TAtTTTCGACAACCTGAAGAAATCCATTGCTTACACCCTGACATCTAACATCCCTGAAATCTCTCCCTTCTTGTTCTTCA $\begin{array}{llllllllllllllllllllllllllllll}765 & \text { I } & F & D & N & \text { L } & \text { K } & \text { K } & \text { S } & \text { I } & \text { A } & \text { Y } & \text { T } & \text { L } & \text { T } & \text { S } & \text { N } & \text { I } & \text { P } & \text { E } & \text { I } & \text { S } & \text { P } & \text { F } & \text { L } & \text { F } & \text { F } & \text { M }\end{array}$ 2401 TGATTGCCTCAGTCCCACTTCCTCTTGGAACTGTGACCATCCTCTGCATtGATCTGGGTACTGACATGGTGCCTGCCATT $\begin{array}{llllllllllllllllllllllllllll}792 & \text { I } & \text { A } & \text { S } & \text { V } & \text { P } & \text { L } & \text { P } & \text { L } & \text { G } & \text { T } & \text { V } & \text { T } & \text { I } & \text { L } & \text { C } & \text { I } & \text { D } & \text { L } & \text { G } & \text { T } & \text { D } & \text { M } & \text { V } & \text { P } & \text { A } & \text { I }\end{array}$

2481 TCCCTTGCCTATGAAGAAGCTGAGTCTGATATTATGAAGCGCCAGCCCCGAAACCCATTCACCGACAAGCTTGTGAACGA $\begin{array}{llllllllllllllllllllllllllllll}818 & \mathrm{~S} & \mathrm{~L} & \mathrm{~A} & \mathrm{Y} & \mathrm{E} & \mathrm{E} & \mathrm{A} & \mathrm{E} & \mathrm{S} & \mathrm{D} & \mathrm{I} & \mathrm{M} & \mathrm{K} & \mathrm{R} & \mathrm{Q} & \mathrm{P} & \mathrm{R} & \mathrm{N} & \mathrm{P} & \mathrm{F} & \mathrm{T} & \mathrm{D} & \mathrm{K} & \mathrm{L} & \mathrm{V} & \mathrm{N} & \mathrm{E}\end{array}$ 2561 GAGGCTCATCTCAATGGCCTATGGTCAGATTGGTATGATCCAGGCCCTGGCAGGATTCTTCACCTATTTCGTGATCATGG $\begin{array}{llllllllllllllllllllllllllllllll}845 & R & L & I & S & M & A & Y & G & Q & I & G & M & I & Q & A & L & A & G & F & F & T & Y & F & V & I & M & A\end{array}$ 2641 CTGAGAACGGCTTCCTGCCACCCCATCTCTTTGGTCTCCGTGAGCGCTGGGACAGTAAGGCCATCAACGATCTGGAGGAT $\begin{array}{lllllllllllllllllllllllllllll}872 & E & N & G & F & \text { L } & \text { P } & \text { P } & \text { H } & \text { L } & \text { F } & \text { G } & \text { L } & \text { R } & \text { E } & \text { R } & \text { W } & \text { D } & \text { S } & \text { K } & \text { A } & \text { I } & \text { N } & \text { D } & \text { L } & \text { E } & \text { D }\end{array}$

2721 CACTATGGACAGGAATGGACCTTCCACGACCGTAAGATTCTTGAGTACACCTGCCACACTGCTTTCTTCACCTCCATTGT $\begin{array}{llllllllllllllllllllllllllllll}898 & H & Y & G & Q & E & W & T & F & H & D & R & K & I & L & E & Y & T & C & H & T & A & F & F & T & S & I & V\end{array}$ 
2801 GATTGTGCAGTGGGCCGATTTGATCATTTGCAAGACCCGCCGTAACTCCATTGTCCACCAGGGCATGAAGAACTGGGTGC

2880

951

2960

977

3040

1004

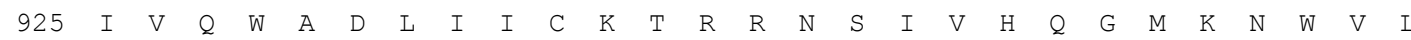

2881 TGAACTTTGGTCTCGTCTTTGAAACCACTTTGGCTGCCTTCCTTTCCTACACCCCAGGCATGGACAAGGGTCTTCGCATG $\begin{array}{lllllllllllllllllllllllllllllllllllllllll}952 & N & F & G & L & V & F & E & T & T & L & A & A & F & L & S & Y & T & P & G & M & D & K & G & L & R & M\end{array}$

2961 TACCCACTGAAGTTCTATTGGTGGCTGCCTGCTCTTCCGTTCTCCATCCTTATCTTCATCTACGATGAGATACGTCGCTT

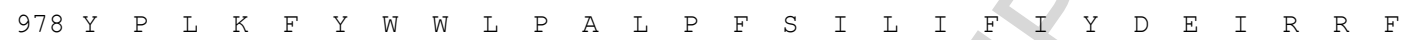

3041 CATCCTGCGAAGGAACCCTGGTGGTTGGATGGAACTGGAGACCTACTATTAA 3092

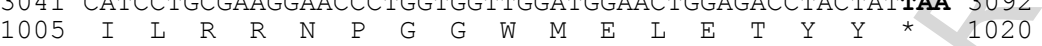




\section{Figure 5}

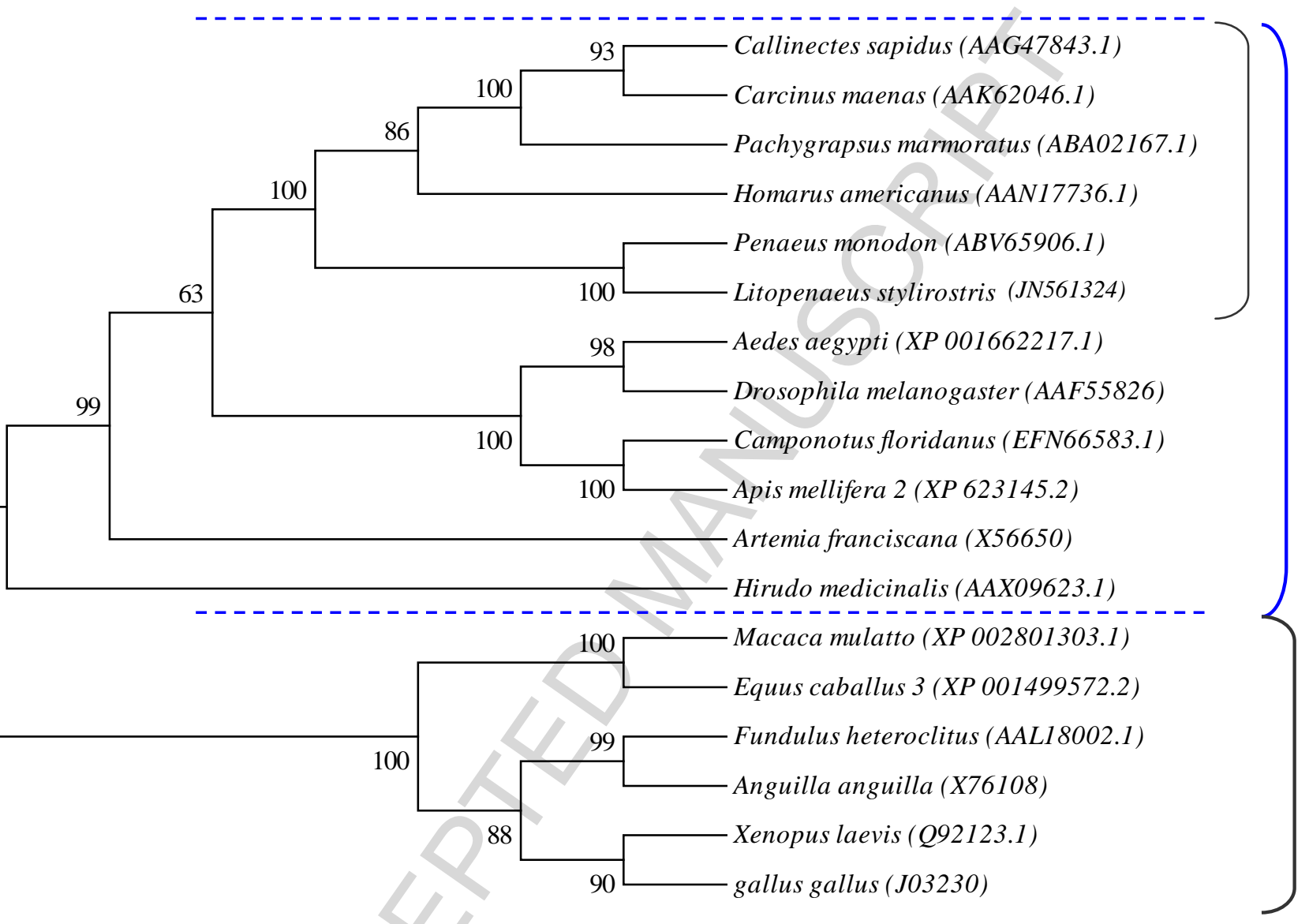

invertebrates

vertebrates 
Figure 6

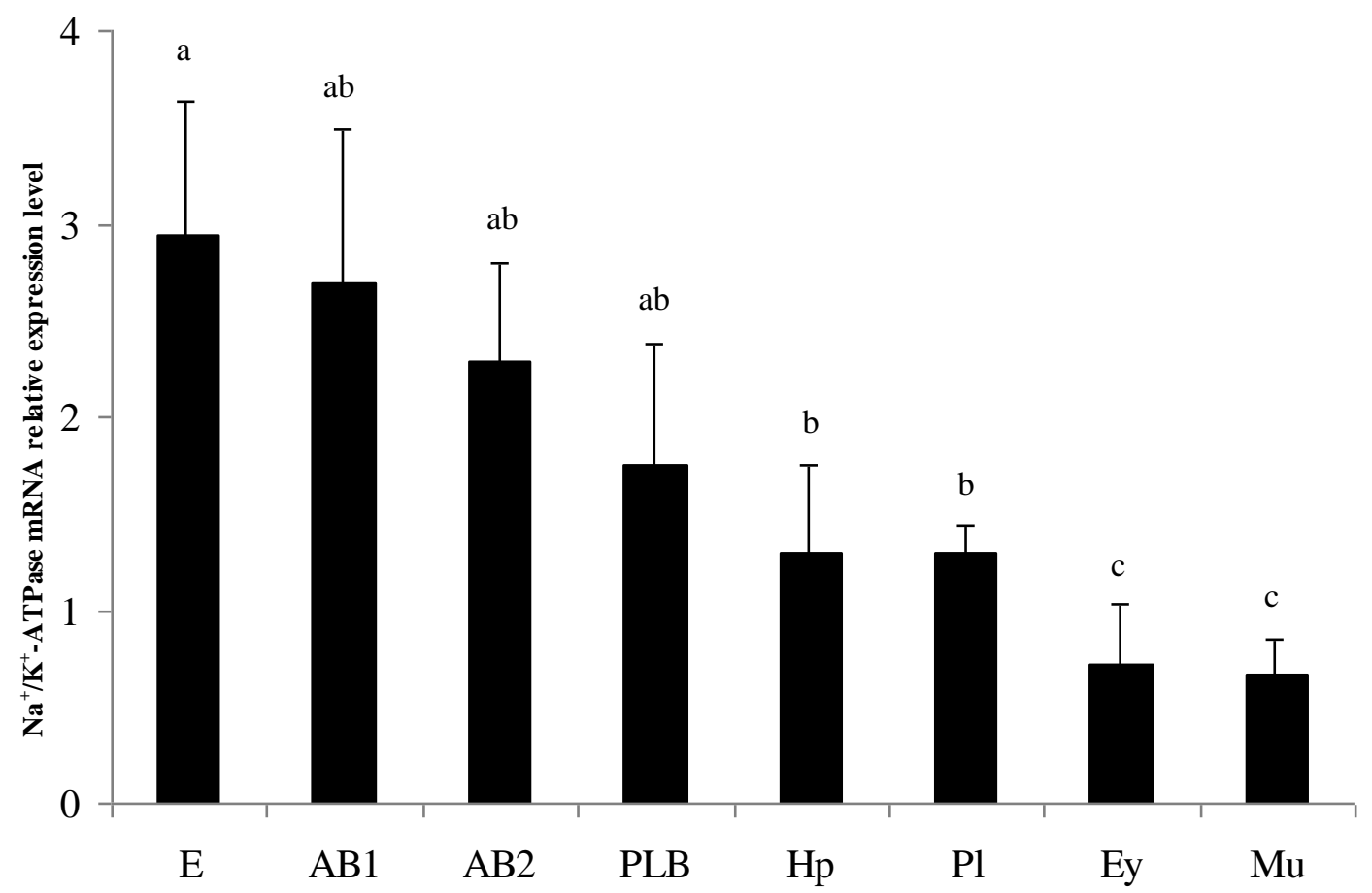


Figure 7

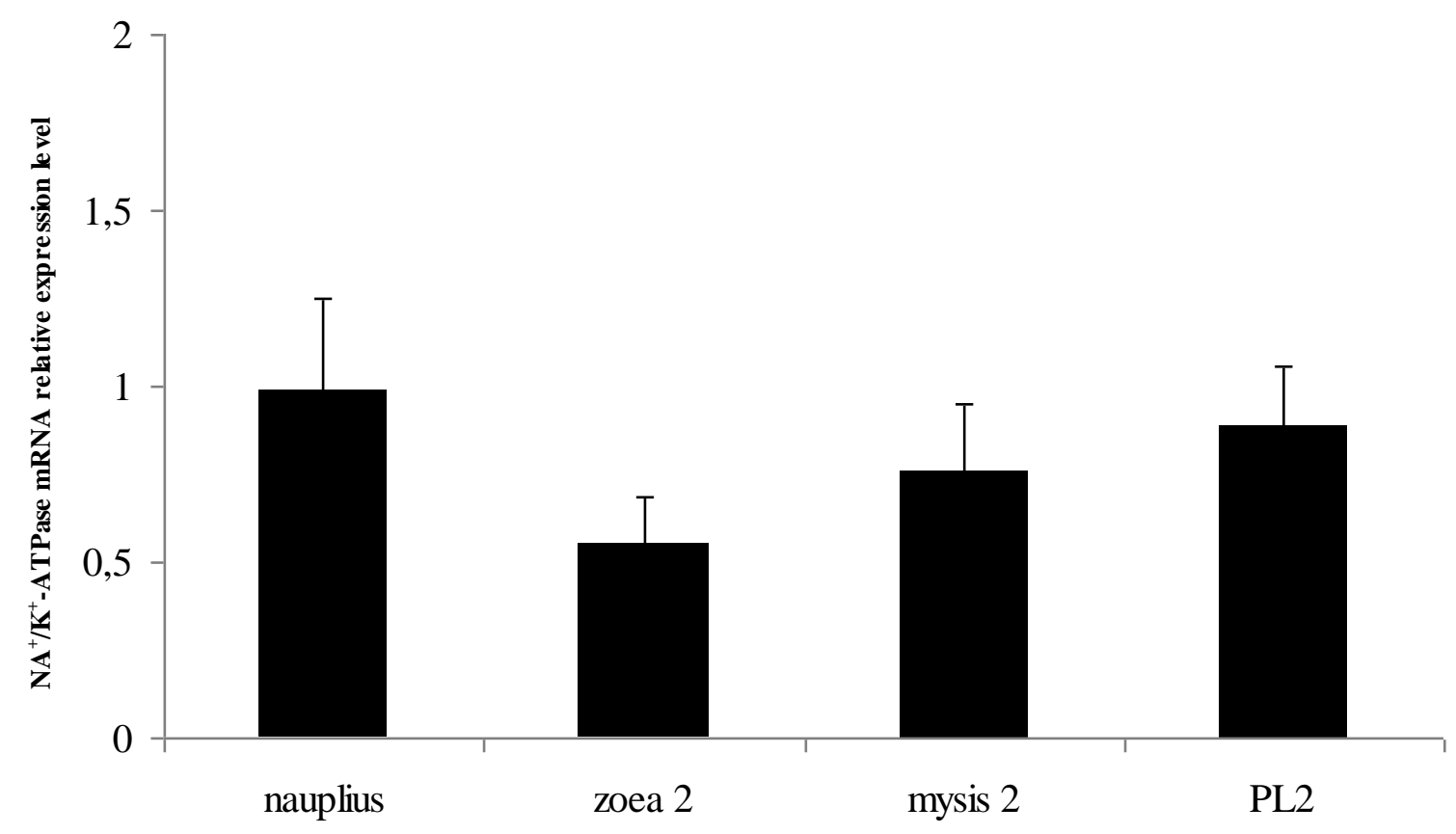


Figure 8

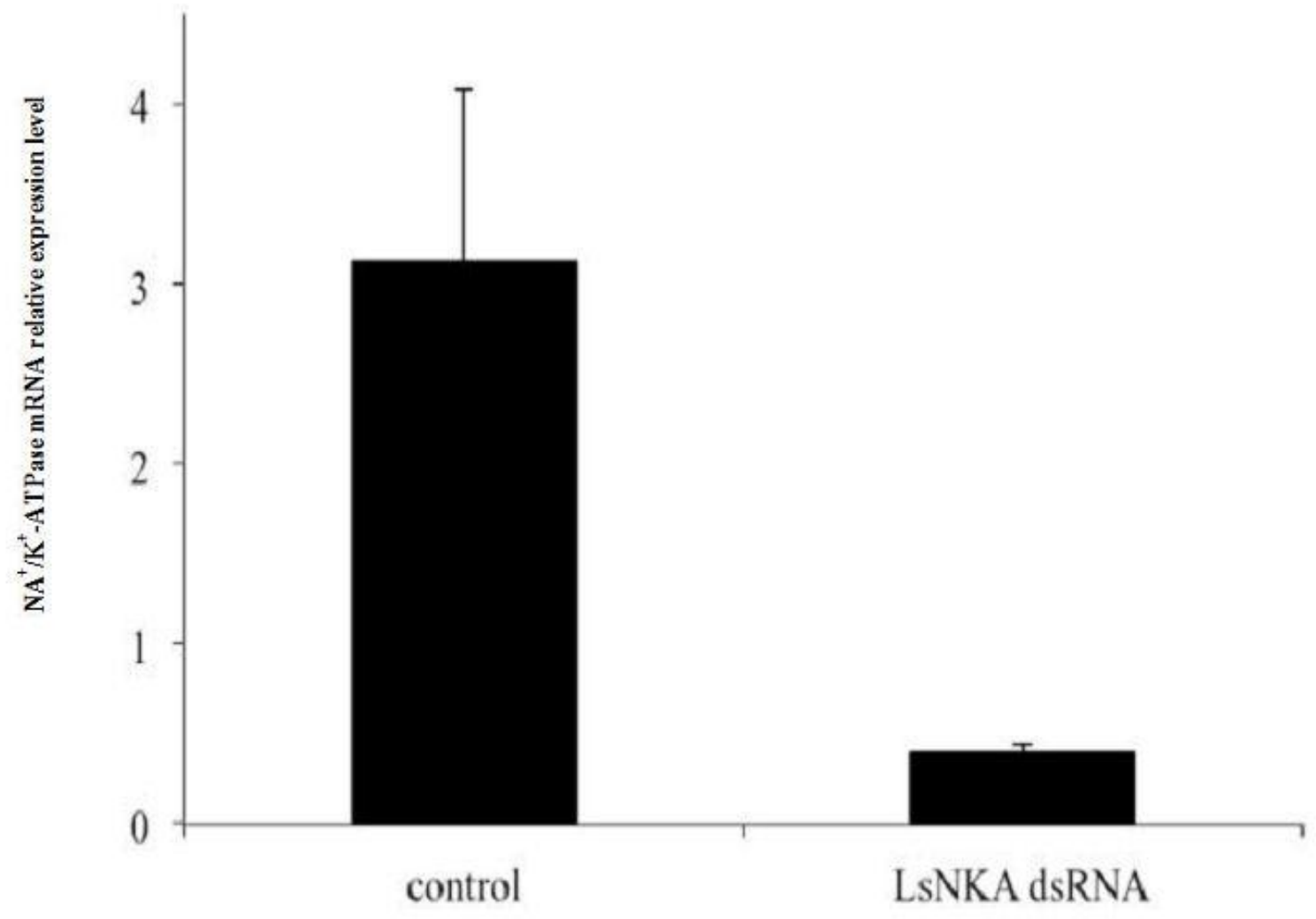


Figure 9

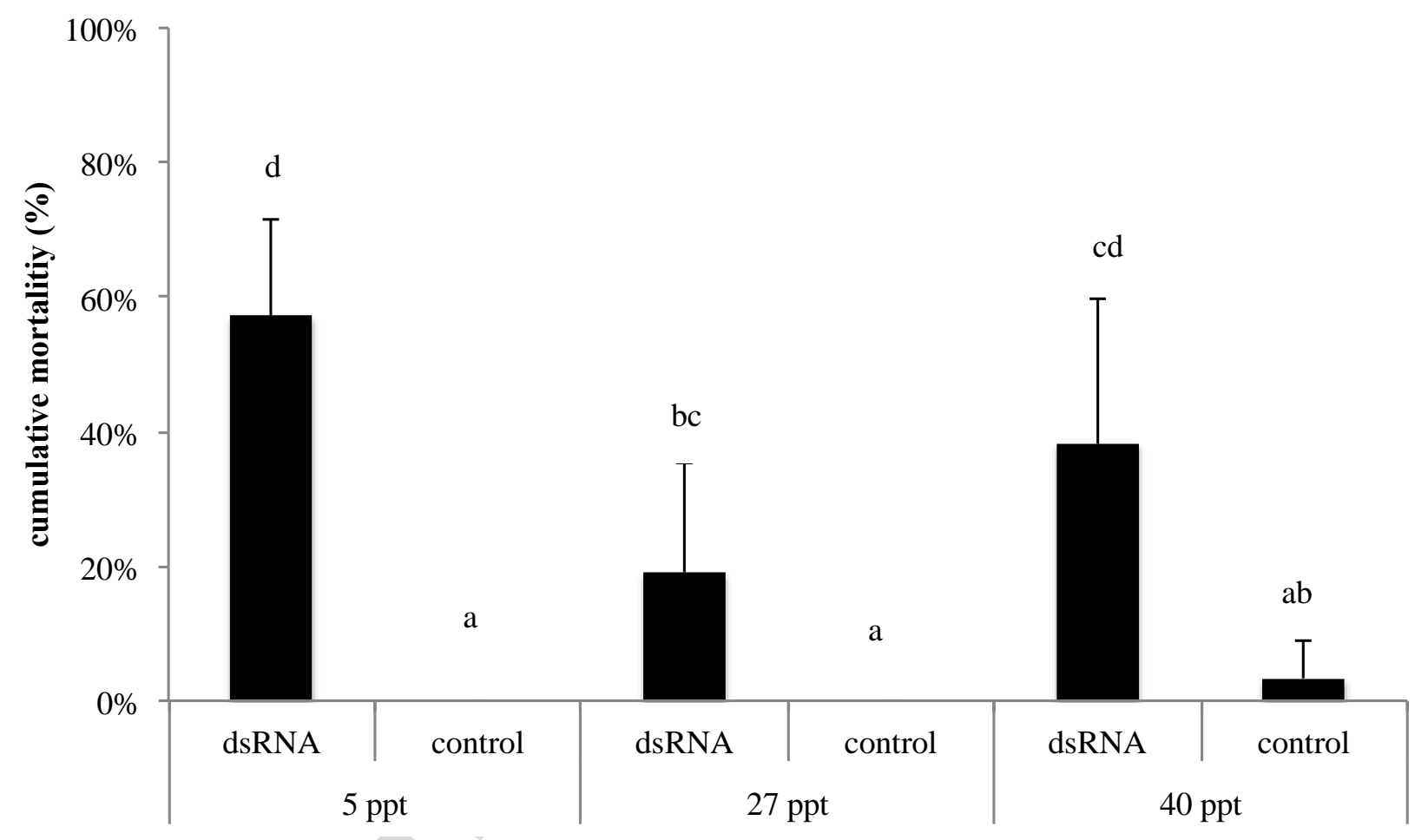

